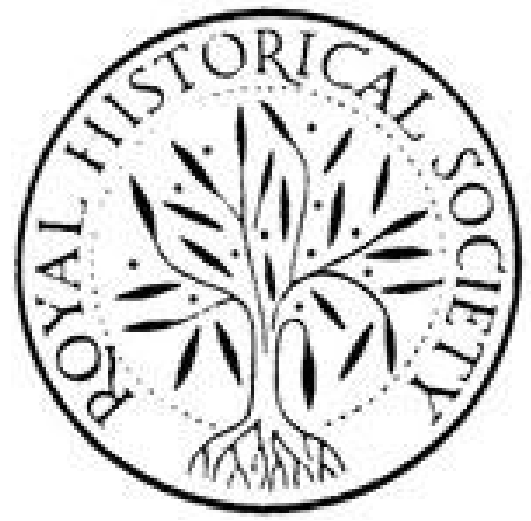

Historical Notes on Some of the Ancient Manuscripts Formerly Belonging to the Monastic Library of Waltham Holy Cross

Author(s): William Winters

Source: Transactions of the Royal Historical Society, Vol. 6 (1877), pp. 203-266

Published by: Cambridge University Press on behalf of the Royal Historical Society

Stable URL: http://www.jstor.org/stable/3677989

Accessed: 28-06-2016 03:08 UTC

Your use of the JSTOR archive indicates your acceptance of the Terms \& Conditions of Use, available at

http://about.jstor.org/terms

JSTOR is a not-for-profit service that helps scholars, researchers, and students discover, use, and build upon a wide range of content in a trusted digital archive. We use information technology and tools to increase productivity and facilitate new forms of scholarship. For more information about JSTOR, please contact support@jstor.org.

Cambridge University Press, Royal Historical Society are collaborating with JSTOR to digitize, preserve and extend access to Transactions of the Royal Historical Society 


\title{
HISTORICAL NOTES ON SOME OF THE ANCIENT MANUSCRIPTS FORMERLY BELONGING TO THE MONASTIC LIBRARY OF WALTHAM HOLY CROSS.
}

\author{
BY WILLIAM WINTERS, EsQ., \\ Fellow of the Royal Historical Society.
}

IT appears from the writings of Eusebius, Basil, Jerome, and Augustine, that libraries were at a very early period attached to various ecclesiastical establishments ; and that these libraries were chiefly composed of liturgical and other service books, together with manuscript copies of the Scriptures (in the original language), homilies, catechisms, psalters, and other similar works. Many of these works were of great value and importance, especially those belonging to the Oriental churches.* And to some of these early houses of worship were attached separate buildings for libraries and schools.

In later times most of the large churches had their Scriptorium, or apartment where the chartularius wrote and transcribed the Ordinals containing the rubric and directory for the priests in service. There were also Collectaries wherein the collects were written, and Troparies, Consuetudinals, etc. Adjoining the Scriptorium was the library proper, which, in most English monasteries, was well stored with choice manuscripts; + there were no fewer than one thousand seven hundred manuscript tracts in the library at Peterborough Cathedral, besides a catalogue of books belonging to the Priory of Dover and the Abbey of St Mary de la Pre at Leicester. + These ponderous tomes of skin, together with a

\footnotetext{
* Riddle's Christian Antiquities, bk. v., p. 69r.

† Hawkins' Hist. Music, vol. ii., p. 254.

† Dugdale's Monasticon Anglicanum, x.
} 
variety of unbound membranes, present a faithful mirror of the general literature of the Middle Ages when the bibliomaniacal spirit of the monkish calligraphists was at its height. As regards their skill in penmanship, they cannot be equalled in the present day. Their works are the principal models of all modern illuminations, and are characteristic of the "patristic eloquence and pious erudition"* of the pre-Reformation period. The style of letter or character used in the Norman period was called Lombardic, and is found in public grants, charters, and law proceedings. This style remained unchanged till the time of Edward III. Caley remarks that the handwriting of ancient records has gradually degenerated from age to age; thus the records of the Saxon era, whether written in Saxon or Latin, are infinitely plainer and more legible than those of subsequent eras; they are also little obscured with abbreviations, which have created much doubt and ambiguity in after-ages. From the reign of William I. to that of Henry III., the charters, grants, etc., are generally found written in a plain and perspicuous hand, and especially those done by the monks, who imitated the modern Gothic characters which were introduced in this country in the twelfth century. $\dagger$ The scribes of the Middle Ages, we are told, carried their writing materials appended to their girdles. These materials consisted of a pen case and an ink horn formed of "cuir bouilli," or "leather softened by hot water, then impressed with ornament, and hardened by baking." A specimen of these useful materials employed by the notaries of the "dark ages," may be seen on an incised brass in St Mary Key Church, Ipswich, temp. Edward IV.+

Consequent upon the dissolution of the monastic institutions of this country in the reign of Henry VIII., most of the ancient libraries were broken up, and many of the rare old manuscripts scattered and destroyed. We are told by the learned Bale, who was no friend of the monks, that "never

* Bibliomania in the Middle Ages (Merryweather), p. 99.

+ Court-hand Restored (Wright), Introd. xi.

† The Book of Days (Chambers), vol. ii., p. I64. 
had we bene offended for the loss of our libraryes, beynge so many in nombre, and in so desolate places, for the more parte, yf the chiefe monuments and most notable workes of our most excellent wryters had been reserved. If there had bene in every shyre in Englande but one solempne lybrarye to the preservacyon of those noble workes, and preferrement of good lernynge in oure posteritye, it had bene sumwhat. But to destroye all without consideracyon, is, and wyll be unto Englande for ever, a most horryble infamy amonge the grave senyours of other nacyons. A great nombre of them, whych purchased those superstycyouse mansyons, reserved of those lybrary bokes, some to serve theyr jakes, some to scoure their candlestycks, and some to rubbe their bootes. Some they sold to the grossers and sopesellers, and some they sent over see to the bokebynders, not in small nombre, but at tymes whole shyppes full, to the wonderynge of foren nacyons. Yea, the unyversytees of this realme are not all clere in this detestable fact. But cursed is that bellye whyche seketh to be fedde with suche ungodly gaynes, and so depelye shameth his natural countrey. I knowe a merchant man, whych shall at thys tyme be namelesse, that boughte the contentes of two noble lybraryes for 40 shillings pryce, a shame it is to be spoken. Thys stuffe hath he occupyed in the stede of graye paper by the space of more than these ten years, and yet he had store ynought for as many years to come. A prodigyouse example is this, and to be abhorred of all men which love their nation as they should." ${ }^{*}$ In the reign of Edward VI. certain of the inhabitants of the parish of Rayleigh in this country met one Sunday afternoon after divine service, and sold, without the consent of the churchwardens, "two missals, two graduals, four processionals, two hymn books, four dirge books, one psalter, four other MS. volumes, and sundry church goods, for the sum of 40s., part of which they gave to the stage players who played at Rayleigh on Trinity Sunday, and the rest they

* Lide Bale's Leland's Laboryouse Journey. 
bestowed upon the reparation of the corn market."* It appears that the king did not trouble much about this kind of book trade nor the council, so long as the books sold did not contain any clasps with "precious metals" upon them. $\dagger$ Some of these ancient service books were curiously embossed and plated with gold and silver, the value of which, not unfrequently, induced certain dishonest persons to steal them for the sake of their covers, despite of the awful anathema appended to many of them against any person who should be guilty of such a deed. The subject-matter of many of these MS. volumes was no doubt literally worthless, full of legends and wonderful miracles that never took place. On this point Fuller remarks that "there were many volumes full fraught with superstition, which, notwithstanding, might be useful to learned men, except any will deny apothecaries the privilege of keeping poison in their shops, when they can make antidotes of them. But besides these, what beautiful Bibles, rare fathers, subtle schoolmen, useful historians, ancient, middle, modern - what painful comments were here amongst them-what monuments of mathematics all massacred together!" $\ddagger$ And Wood informs us that upwards of a cartload of valuable MSS. were removed from Merton College and destroyed, also many from the Oxford Colleges. Although many of the early MSS. which once adorned the library of the monastery of Waltham Holy Cross are lost, yet a few are preserved in the collections of MSS. in the British Museum and elsewhere. Doubtless several valuable MSS. were destroyed in I73I in the fire of the Cottonian Library. One of the most important of the Waltham Registers was materially injured in that conflagration. The library of Sir Robert Cotton originally consisted of 958 volumes, which number was reduced by the fire to $86 \mathrm{I}$

* As recently as the year I790 no fewer than 4, 194,000 volumes belonging to monasteries were burnt in France, and out of this number 25,000 were manuscripts.

† Essex Arch. Soc. Trans., vol. iii., p. 202.

‡ Church History, bk. vi., p. 335 . 
volumes, and out of them 105 volumes were found to be much damaged when brought to the Museum. The Waltham Register (Cott. MSS., Tiberius, c. ix.) was among those damaged. The few remaining Waltham MSS. have passed through a series of changes within the last four or five centuries, and some are now bound up with contemporary parchments, and preserved among other national monuments in the British Museum and the Public Record Office. In his account of the "English Monastic Libraries," Joseph Hunter notes under Waltham that "the library of this house contained several of Stephen Langton's Commentaries-the ÆEnigmata of Aldhelm, Simphosius, Eusebius, and Tatwin; with the Vocabularius, or Elucidarium Bibliothecæ of Alexander Necham. There were a few other books." The Cottonian MS. contains an account of the Great Charter of Waltham (folio 48), and is noticed in the catalogue as "Registrum Monasterii S. Crucis de Waltham in com. Essexiensi; continens nimium chartas regias, pontificales, episcopales, et alias, de prædiis, terris, privilegiis, juribus, ecclesiis, indulgentiis, aliisque ad idem monasterium spectantibus." It also contains a variety of historical matter other than that of Waltham, i.e., (I.) "Vita Reg. Ricardi II. scripta a quodam monacho de Evesham." (2.) "Libertates a rege Gulielm. II. Anselmo archiep. Cantuar. concessæ." (3.) "Historiola de magna convocatione nobilium et seniorum, A. I072; de quibusdam consuetudinibus et terris, quas Lanfrancus Cantuar. archiep. ex jure suæ ecclesiæ, ad se pertinere proclamabat." (4.) "Libertates et privilegiæ concessæ a R. Gulielmo monachis de S. Trinitate Cantuariæ." (5.) "Libertates a R. Henrico I. Anselmo archiep. Cantuar. et Eccl. Christi Cantuariæ concessæ." (6.) "Archidiaconatûs Cantuariensis institutio et jura: ubi de lite inter archidiaconum et capitulum de jurisdictione administranda, vacante sede archiepiscopali." This volume consists of 258 folios, and is beautifully written on vellum. The part which suffered from fire in I73I is perfectly restored, with the exception of a slight contraction of the margin. This manuscript is nearly 
as old as the original from which it was copied. It was compiled late in the twelfth century by a Waltham scribe, probably one of the ejected canons. From the body of the work we are enabled to glean a little of the life of its author; this has been ably done by Professor Stubbs. It has been said that old charters can never be made light reading, and that all persons who care for or could use the information they contain, would prefer to see the words in which they were written.* But when we have before us such an account of the early historian as is given by $\mathrm{Mr}$ Stubbs in his introduction to the "De Inventione Sanctæ Crucis Waltham," + we deem it best to leave the original for the present, and satisfy ourselves with the following:

"As we do not know our author's name, what little we are able to learn of him is drawn from his book [Cott. Tib. c. ix.]. Since he entered the house [of Waltham] at five years of age, continued in it fifty-three years, and was expelled in II 77 , he must have been born in II I9, and commenced his education in II24. For two years he was in association with the sacristan Turkill, from whom he heard all that was marvellous and legendary in the story of the founders. He was brought up in the school of the college under Master Peter, the son of Athelard. In time he became a thuribularius, a trebler, or censing chorister, and was in his weekly turn when the miraculous cure of Matthew took place. As he would not be more than fourteen, we are enabled to approximate to the date of that event. It must have been not later than ir 33. He was made a canon early in life; for in I 144, when the houses were burned, he was one of the sufferers. $f$ He owed his promotion to Dean Ernulf and Queen Adelicia. Supposing the restoration of the latter to have occurred in I I $4 \mathrm{I}$, when the empress was decidedly in the ascendant, the date would fall between II4I and II44. His youth would be no objection, if in this church as in St Paul's, it was intended that there should be always canons of the three orders of priest, deacon, and sub-deacon. He leaves us in doubt of his expulsion in 1177 ; nor,

* See Antiquary, vol. ii., p. 27.

+ Vide p. xxvi.

¥ These houses belonged to the canons of Waltham. They were destroyed in an attack upon the town and church by Geoffrey de Mandeville, who was in feud with William of Albini and others. 
we may remark, does he ever allude to the circumstances which were made a ground for that measure. It is from the Austin canons that we learn that it was for careless and secular lives."

The most interesting part of the manuscript before us is the foundation charter of Harold's Church at Waltham, which is dated M.LXII., two years after the consecration of the building. Some considerable perplexity has arisen in the minds of not a few writers respecting the correct date of the foundation of Harold's Church, which will be seen if we compare the account given in the "De Inventione" with Kemble's "Codex Diplomaticus" (vol. iv., No. 813), Dugdale's "Monasticon," and the Essex Archæological Society's “Transactions," vol. ii., 59, in which last-mentioned work the learned writer concludes, "that the date of the dedication was May 3, I060." It is just possible that the building was but partly erected at this time, and rendered suitable for the dedication service. Mr Stubbs, in his concluding remarks respecting the date of the charter, writes :

"We must suppose, therefore, that the charter of Edward was executed two years after the dedication, and that the attestations are those of the persons who witnessed the execution; that the Waltham scribe knew by the tradition of the house that Kinsi was the consecrator, and not remembering the inconsistency of the dates, copied the names of the witnesses from the charter, on the idea that they were present at the ceremony; and that thus, with the single exception of this mistake, both accounts are genuine and consistent."*

We present a transcript of the great charter of Waltham (Cott. MSS., Tib. C. ix., f. 40): $†$

"In nomine Domini nostri Jesu Christi, qui unus Deus in Trinitate ab omnibus se colentibus veneratur et puro cordis affectu adoratur. Ego Edwardus Dei dono Anglorum rex in hujus mundi decursu, hujus

* Archæological Transactions, vol. ii., p. 60.

† See Mr Stubbs' tract, The Foundation of Waltham, app. ii., p. 46. 


\section{TRANSACTIONS OF THE ROYAL HISTORICAL SOCIETY.}

seculi filiorum qui justi inveniuntur studens exaltare cornu, ut portæ regalis imperii, jure rite roborati, accedant ad eum per callem justitiæ qui dat petentibus juste et religiose vivere. Hæc tamen beata commutatio digne censetur in hoc seculo, ut cui felicitas tantum deliberaverit, animi quod mundialium cupiditatum postposita, velut granum frumenti a spinis suffocantibus aliquando vero dumetis arescentibus, decipiat, in hunc tenorem emergi ut divina virtute firmatus vigeat suo Creatori et Domino. Istas etenim inter transitorias mundi procellas cuidam meorum comitum onomate Haroldo quandam terram quæ antiquitus ab incolis illius loci nuncupatur Waltham, hereditario jure concessi cum ornnibus ad se pertinentibus campis pascuis pratis silvis et aquis. Exhinc sibi tantam Deus suæ pietatis gratiam contulit ut inter momentanea mundi desideria cogitaret feliciter desiderando celestia. Quinetiam ille, qui omnia in omnibus operatur ut vult talem divinæ pietatis dulcedinem ut suprammemoravi, concessit ei ut non solum Dei cultor efficiatur verum etiam canonicæ regulæ strenuus institutor fieri credatur; nam hæc divinitus fidei declaratione et operum exhibitione ceterarumque æcclesiarum rerum plenitudine probavit eventus. Quis autem finis ejus desiderii post hæc evenerit sapientia per Salomonem declarando prompsit, dum ait justis dabitur desiderium bonum. Enimvero rationali consilio ditatus ac suæ non immemor conditionis in prescripto loco monasterium ad laudem Domini nostri Jesu Christi et sanctæ crucis construxit. Primum concedens ei terram quæ vocatur Northlande unde æcclesiam villæ antiquitus dotatam invenit post fundatum dehinc sacræ fidei monasterium, ad normam sanctæ Dei ecclesiæ dedicari fecit, honorifice ob memoriam mei et conjugis meæ nomine Eadithæ patris ac matris pro se, suisque omnibus vivis et defunctis sibi consanguinitate conjunctis. Hoc enim perplurimis sanctorum apostolorum martyrum, confessorum virginum reliquiis ornavit. Hoc non solum terris quarum vocabula post hæc sunt recitanda, verum etiam libris evangelicis, vestibus ac diversis ornamentorum generibus templo Domini congruentibus qui divinis cultibus clare ac dulcedine imbutus attentius, sanctæ celebrationis templum excolere cæpit ac venerari. Quid plura? Suae denique conditionis non immemor ibidem quorundam catervulam fratrum secundum auctoritatem sanctorum patrum, canonice regulæ subjectam, constituit quæ Deo et sanctis ejus, die noctuque laudes hymnizando, decantet. Hæc sunt vocabula prædiorum ad præfatum pertinentia monasterium. 
"Passefelda, cum omnibus ad se pertinentibus campis pascuis, pratis silvis et acquis.

Walde.

Vpminster.

Wahlfare.

Tippedene.

Alwartune.

Wodeforda.

Lambehide.

Nesingan.

Brikendune.

Meluho, cum omnibus ad se pertinentibus.

Alricheseia.

Wrmeleia.

Nethleswelle.

Hicche, cum omnibus ad se pertinentibus, campis, pascuis, pratis silvis et aquis.

$\left.\begin{array}{l}\text { Lukintone, } \\ \text { West Waltham. }\end{array}\right\}$ cum omnibus ad se pertinentibus.

" Has omnes supradictas terras Ego Edwardus Rex pro redimendis peccatis meis et antecessorum sive etiam successorum meorum consilio archiepiscoporum et episcoporum necnon et principum terræ meæ ecclesiæ sanctæ crucis et fratribus ibidem in Dei nomine congregatis, sive congregandis, concedo, cum sacha et soche sol et team, et infangenethof, et flemenes fyrithe, et gridbreche, forstal, hamsokne, blodwite, odel, et oreste. Si vero aliquis successorum meorum quod absit de terris istis quicquam subtraxerit vel subtrahi permiserit et inde requisitus, emendare noluerit, ei Deus justus, judex, regnum pariter et coronam auferat. Nos autem, archiepiscopi, et episcopi ad hanc confirmationem congregati ex precepto Domini Regis ejusdem hortatu excommunicamus et maledictione perpetua, condemnamus omnes transgressores hujus consularis donationis et regularis concessionis [Here follow the land boundaries of the church].

"Ego Edwardus natu divino Rex, omnia prædia quæ Haroldus comes monasterio apud Waltham subjecit vel quæ adhuc se daturum decernit, sublevans statuo ut ab omni servitutis jugo sint semper libera et a shiris et hundredis et extra curiam sanctæ crucis omnibus 


\section{TRANSACTIONS OF THE ROYAL HISTORICAL SOCIETY.}

placitis et omnibus geldis. Scriptum est autem istud privilegium anno Dominicæ Incarnationis M.LXII.

"Indictionibus ter quinis epactis septenis, concurrente I. Hiis testibus consentientibus. Ego Edwardus Anglorum Basileus hac inscriptione $\$$ Salutiferæ crucis deliberando assigno. $\$$ Ego Eadgytha Dei munere Christi Regina hæc eadem confirmando testimonium do. Ego Stigandus Dorobernensis archipresul hæc eædem affirmo:

Ego, Ealdredus, Eboracensis Ego, Eadmundus, Abbas. archiepisc., hæc consolido. Ego, Sichtricus, Abbas.

Ego, Alfwoldus, episc., ad hæc Ego, Haroldus, comes operando testimonium perhibeo.

Ego, Hermannus, episc., testimonium exhibeo.

Ego, Leofriccus, episc., testimonium adhibeo.

Ego, Willielmus, episcopus, hæc affirmo.

Ego, Ailmarus, episc., hæc consolido.

Ego, Lefwinus, episc., testimonium perhibeo.

Ego, WhFwinus, epis., hæc eadem confirmo.

Ego, Aelwinus, episc., testimonium exhibeo.

Ego, Africus, episc., hæc affirmo.

Ego, Walterus, episc., hæc eadem corroboro.

Ego, Gyso, episc., hæc omnia præscripta confirmo.

Ego, Ægelnothus, Abbas.

Ego, ÆLphwinus, Abbas.

Ego, Wllfricus, Abbas.

Ego, Leofricus, Abbas.

Ego, Leofstanus, Abbas.

Ego, Ælwig, Abbas.

Ego, Hordricus, Abbas.

Ego, Ægelsinus, Abbas.

Ego, Leofstanus, Abbas.

Ego, Elffarus, comes.

Ego, Tostinus, comes.

Ego, Leofwinus, comes.

Ego, Gyrth, comes.

Ego, EsGaRus, regiæ procurator aulæ.

Ego, Rodbertus, regis consanguineus.

Ego, Radulphus, regis aulicus.

Ego, Bundinus, regis palatinus.

Ego, Hesbernus, regis consanguineus.

Ego, Regenbaldus, regis cancellarius.

Ego, Petrus, regis capellanus.

Ego, Baldewinus, regis capellanus.

Ego, BRIhTricus, princeps.

Ego, Ælfstanus, princeps.

Ego, Wigodus, regis pincerna.

Ego,HERdINGUS, reginæ pincerna.

Ego, Adzurus, regis dapifer.

Ego, YFIngus, regis dapifer.

Ego, Godwinus, regis dapifer.

Ego, DoDDo, princeps.

Ego, Alfgarus, princeps.

Ego, Brixinus, princeps.

Ego, Egelnothus, princeps. 
Ego, Essernus, princeps. Ego, ADwIG, princeps.

Ego, EDRICUs, princeps. Ego, Ægelmundus, princeps. Ego, Siwardus, princeps.
Ego, Alwoldus, princeps. Ego, ÆLPHig, princeps.

Hæc ego subscripsi Swithar subnomine Christi. 4

It is questionable whether all the persons whose names appear in the transcript were present at the dedication under the style in which they appear here, as Walterus et Giso, Bishops of Cirencester, were not consecrated until I06I (see "De Inventione"). The charter is subscribed by thirteen bishops, all that were in this country at that time. There is, however, a little perplexity in the signatures, arising from the non-appearance of the name of "Siward of Rochester," while that of Elfwold-probably of Sherborne-is given, and he died in 1058 , two years before the consecration of the church. We recognise the names of eleven abbots, and prominent among them is the Glastonbury abbot, झthelnoth, with the abbots of Peterborough, Abingdon, and Ramsey. These are followed by five earls, chief of whom is Harold, whose signature appears under the following form, "Ego Haroldus comes operando consolido," accompanied by those of Elfgar, Tostig, Leofwine, and Gyrth, who played a conspicuous part in the wars that preceded the Norman Conquest. After these are the signatures of twenty-six thanes and officers of the king's court, the lowest of which bears the title of "princeps," and there are other notable characters whose names are embalmed with those of other Norman officials in "Doomsday Book."

Much general interest is associated with the lives of the witnesses of this great charter. A brief outline of them may not be inappropriate :

\section{EADWARD AND EADGYDA.}

One of the most prominent characters in the charter is Edward the Confessor, son of Ethelred II., ${ }^{*}$ by Emma, his

* Born 968; began to reign 978; ob. 23d April ror6. Married (1.) Ælflæd, daughter of Thored; (2.) Emma or Elfgifu, daughter of Richard I., Duke of Normandy, ob. March 1052 (Lappenberg, vol. ii., p. 369). 
second queen. His reign, which commenced A.D. I042, was tranquil and prosperous. After the death of Hardicanute on June 8th of this year, we are told that "before he was buried all the people chose Eadward king in London." The "AngloSaxon Chronicle"* informs us further, i.e., "An. M.XLIII.In this year Eadward was hallowed king at Winchester, on the first Easter Day, with great worship; and then was Easter on the iiird of the Nones of April (April 3d). Archbishop Eadsige hallowed him. . . . And Stigand the priest was blessed bishop of East Angles. And shortly after the king caused all the lands which his mother possessed to be seized into his hand; and took from her all that she possessed in gold, and in silver, and in unspeakable things, because she had before held it too strictly towards him. And soon after Stigand was deposed from his bishopric, and all that he owned was seized into the king's hand; because he was closest in his mother's counsel, and she went as he advised her, as it was supposed." Eadward was forty years of age when he married Eadgyth, the eldest daughter of Godwine, Earl of Kent, + who died in the December of 1074 ; they were married on the 23d January 1045. After the death of Edward she was allowed by William the Conqueror to retain her jointure city of Winchester and other landed possessions. Her name appears in the charter; she is described as being no less highly gifted among women than her brothers were among men, as being lovely in person and adorned with every female accomplishment, and as endowed with a learning and refinement unusual in her age; altogether she was considered a fitting helpmeet for Edward himself. But there are strange inconsistencies in the facts which are recorded of her. She is said to have sat at her husband's feet until he

* Thorpe, vol. ii., p. r 33 .

+ "Of Elmham."

¥ King Edward, says Fuller, was "absolutely father-in-law-ridden. This Godwin, like those sands in Kent which bear his name, never spared what he could spoil, but swallowed all which came within his compass to devour." Edward did a great public good in remitting the Danegelt Tax, and in sweeping away other oppressive measures imposed upon the country by previous rulers. 
lifted her up to sit at his side.* Nearly a century after King Edgar had repaired Westminster Abbey and endowed it with lands, etc., Edward the Confessor raised the structure to the consequence which it has since maintained. The king fixed upon the abbey as his place of interment. He devoted to the work of restoration a tenth part of his possessions in gold, silver, and cattle. The abbey was completed in 1065. The king was not well enough to be at the dedication which took place on the 28th of December, for on Christmas he was taken ill, and he died on the 5 th of January. On the I 2 th of the same month his body was interred with great pomp before the high altar, in what is called the Chapel of St Edward.

This marriage of Edward with Eadgyda brings us into close proximity with Harold; thus, Eadgyth (Editha), queen of Edward, was the sister of Harold. Hence we have it:

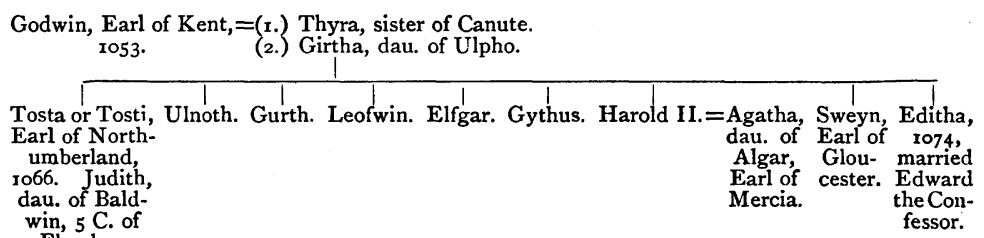

\section{ARCHBishop Stigand.}

Stigand, whose name is given in the charter, was chaplain to King Edward, and Archbishop of Canterbury. He had been King Harold's chaplain, and Bishop of Sherborne, from thence he was translated to Winchester, which he kept together with the archbishopric of Canterbury with the king's consent. He was guilty of what was deemed a flagrant irregularity, in making use of his predecessor's pall, which was contrary to the canon; and he was afterwards guilty of one still greater, in receiving his own pall from Pope Benedict, whom the Church of Rome had excommunicated. As soon as the Conqueror was seated on the throne, Stigand was deposed by him; and so fearful was he of this prelate's disposition towards him, that when he returned into Normandy

* Freeman's Hist. Nor. Conq., I870, vol. ii., p. 45. 
in 1067 , he took Stigand with him, among others. This archbishop was first formally suspended by the papal interdict, and at last in the octaves of Easter, anno 1070, degraded and deprived of the archbishopric, with the pope's consent, by his legate and two presbyter cardinals, for the above-mentioned causes; after which he was put into prison, where he died, and was buried at Winchester. Here his remains rested till the fourteenth century, when Bishop Fox built two walls in the church dividing the presbytery from the side aisle; on one of which he placed the leaden chest containing the bones of this prelate. The inscription thereon was, "Hic jacet Stygandus Archiepiscopus." In 1642 this chest was again disturbed and broken into by Colonel Sandys and his forces, who employed the bones in breaking the painted glass windows of the abbey. The bones were again collected and enclosed with a chest, and placed upon the same wall in I66I.*

\section{ARCHBISHOP EALDRED.}

Following the names as they appear in the MS., we shall next notice Ealdred (or "Ealdeo"), whose first appearance is that of Abbot of Tavistock. This famous man succeeded Lyfing as Bishop of Worcester in 1046. His early career had led him through almost the same stages as that of his predecessor. "Like him he had been a monk at Winchester, like him he had been thence called to the government of one of the great monasteries of the west." He was a man of great ability, and exhibited, like Harold, a better form of the increasing connection between England and the Continent. As an ambassador at the imperial court, as a pilgrim at Rome and Jerusalem, he probably saw more of the world than any contemporary Englishman. He was renowned as a peacemaker, one who could reconcile the bitterest enemies. But, in common with many other prelates of his time, he did not escape the charge of simony. Ealdred did not scruple to bear arms both in domestic and in foreign warfare; but his campaigns

* See Hasted's Hist. Kent, vol. iv., p. 689. 
were, to say the least, not specially glorious. His most enduring title to remembrance is, that it fell to his lot to place, within a single year, the crown of England on the brow, first, of Harold, and then of William, and to die of sorrow at the sight of his church and city brought to ruin by the mutual contentions of Normans, Englishmen, and Danes.*

In 1050 Ealdred assisted in repelling an invasion from Ireland. Six years after we find him in arms with Harold against the Welsh. In 1060 he succeeded to the archbishopric of York. In 1067 he crowned Matilda at Westminster, and in 1069 he died and was buried at his episcopal see, after he had held the archiepiscopal chair with great dignity for ten years.

\section{BISHOP ÆLFWOLD.}

Ælfwold (or Alfwold) was Bishop of Sherborne (at least he is identified as such by Freeman, $\uparrow$ who says he died in 1058, two years before the foundation of Waltham). He was famous for his temperance and frugality in a luxurious age. Knighton says he was a monk of Winton in the time of Edward the Confessor. $\ddagger$ Malmesbury relates the dreadful effects of his curse denounced against Earl Godwin, with whom he had a dispute; and his extraordinary affection to St Cuthbert, whose shrines he visited.

\section{Bishop HeremanN}

was chaplain to Edward the Confessor in 1045, when he succeeded Brithwold, or Æthelwin, at Wilton. On a vacancy in the Abbey of Malmesbury, he petitioned King Edward to have this transferred thither. This the king readily granted, but Earl Godwin and the monks got it reversed. Upon this disappointment, Heremann (or Herman) retired into France, and became a monk at Bertin (I055), where he stayed three years; but on the death of Athelwold (or Athelwin), Bishop of Sherborne, he returned home and was made bishop of

* Norman Conquest (Freeman), vol. ii., p. 86.

† Vide Norman Conquest. $\quad \ddagger$ Hist. Devon. (Hutchin), vol. iv., p. 9r. 
that see in 1058. He afterwards went to Jerusalem. In I07 I he assisted in the consecration of Lanfranc, Archbishop of Canterbury; he died in I074. The "Anglo-Saxon Chronicle" * records that he died "an. M.LXXvirI.", and that he was Bishop of Berkshire, and of Wiltshire, and of Dorsetshire. He was believed to have been a native of Flanders or Lorraine. Mr Freeman calls him "Hermann of Lotharingia."

\section{BISHOP LEOFRIC.}

Leofric or Lewric, the last Bishop of Crediton, signed the charter as bishop. He obtained from King Edward the Confessor permission to transfer the seat of his diocese to Exeter, A.D. I050. This prelate is said to have been by birth a Burgundian. King Edward the Confessor and his queen are stated to have enthroned Leofric in person in his new cathedral. William of Malmesbury is minute upon the subject of the change which Leofric made when he ejected the monks, and substituted secular canons here. Leofric died on the Ioth February 1073, and was buried, according to Hooker and Godwin, in the cemetery of his church under a plain stone. $\dagger$

\section{BISHOP WILLS,}

or William of London, according to Mr Stubbs. + Newcourt states that he was a Norman chaplain to King Edward the Confessor, and was consecrated Bishop of London A.D. I05 I, in the month of September. $\mathrm{He}$ is in other places called "William Primus," and is said to have died circa I067.§ For several centuries the Londoners made an annual pilgrimage to the tomb of this bishop in the nave of St Paul's. His epitaph bore witness to their great reverence. In the seventeenth century (A.D. I622), the Lord Mayor, Edward Barkham, caused these quaint lines to be inscribed on the tomb of Bishop William:

" Walkers, whosoe'er ye be,

If it prove you chance to see

* Thorpe.

$\ddagger$ Invent. S. C. W., p. 19.
† Monasticon, vol. ii., p. 514 .

$\S$ Repertorium, vol. i., p. II. 
Upon a solemn scarlet day,

The City Senate pass this way,

Their grateful memory for to shew,

Which they the reverent ashes owe

Of Bishop Norman here inhumed;

By whom this city has assumed

Large priviledges : those obtain'd

By him when Conqueror William reign'd.

This being by Barkham's thankful mind renew'd,

Call it the monument of gratitude."

This monkish procession continued annually until the accession of Queen Elizabeth.*

\section{Bishop Ailmarus.}

Ailmar or Almar, who was brother to Stigand, Archbishop of Canterbury, was Bishop of Elmham, county Norfolk, in the time of the Confessor. The principal of the lordship of Boyton, in this county, was purchased by him, the whole of which was then valued at $\AA^{6}$. On his deposition in I070, it was granted by the Conqueror to William, his chaplain and the Bishop of Thetford. Little else is known of this prelate, other than that he had been Abbot of Coventry.

\section{BISHOP LEFWINUS.}

$\mathrm{He}$ is generally called Leofwin of Lichfield, consecrated to this see A.D. I053. The "Saxon Chronicle" informs us that "Leofwine and Wulfwi went over sea, and there caused themselves to be ordained bishops." He died in 1066.

\section{BishoP WLFWINUS.}

Mr Stubbs classifies Wulfwin (or Wlfwinus) as Bishop of Dorchester. It is hard to identify this person with Wulfwig, who was Bishop of Dorchester, and died a year after the Norman Conquest. He was probably the Wulfwin who was Harold's chaplain, and appointed by him as the first Dean of Waltham. +

* Annals of St Paul's (Milman), p. r6. † Bloomfield's Hist. Norfolk, vol. v. ¥ See list of deans, etc. 


\section{Bishop Aelwinus,}

or Ælwin of Durham.*

\section{BISHOP AFRICUS,}

or Æfric of Selsey.† Mr Freeman states that " Ethelric, Bishop of the South Saxons, appears under the corrupted form of 'Affricus."'

\section{BISHOP WALTER.}

Walter, a Lotharingian by birth, was chaplain to the Lady Eadgyth. He was collated to the bishopric of Hereford, A.D. I060, and died circa I079.+

\section{Bishop Gyso.}

Both Walter and Giso (or Gisa) were Lotharingian bishops. They both survived the Conquest, and the latter survived the Conqueror himself. There is nothing to convict either of them of treason to England ; but Gisa at least does not seem very warm in his patriotism for his adopted country. $\mathrm{He}$ is quite ready to forgive William for the conquest of England in consideration of the help which he gave him in his reformation of the church of Wells. Walter, on the other hand, is represented in some accounts as taking a prominent part in resistance to the Conqueror. Both Walter and Gisa kept their sees till death. Walter, we are told, came to a sad and shameful end. Gisa lived and died in honour, and his life occupies a prominent place in the "History of the Church of Wells." Giso of Wells and Walter of Hereford were consecrated at Rome by P. Nicholas II. Giso died A.D. 1088. $\mathrm{Mr}$ Freeman has given the dispute between Giso and Harold in extenso.\$

The bishops are followed on the list by the abbots.

\section{ABBot Ægelnophus.}

Ægelnophus, Egelnoth, or Ailnothus, was the last Saxon

* De Invent. S. C. W., p. 19 (Stubbs).

$\S$ See Hist. Nor. Conq., vol. ii., p. 446.

$+I b$.

$\ddagger$ See infra. 
Abbot of Glastonbury, county Somerset, and, according to the "Saxon Chronicle," was deposed in A.D. I077. He was considered one of the principal men in the nation at the time of the Conquest, for which reason the Conqueror carried him to Normandy, together with the principal nobility and gentry, being jealous of his power and influence. $\mathrm{He}$ was then deprived of his abbacy.*

\section{AвBOt ÆLPHWINUS.}

I imagine that this person was no other than Ælfwine, Abbot of Ramsey, who, according to the "Anglo-Saxon Chronicle," was sent to the synod at Rheims in I046. There was an ecclesiastic of the same name who died in his bishopric in the following year. $\mathrm{Mr}$ Stubbs states that he was Abbot "of Hyde."

\section{ABBOT WlFFRICUS.}

Stevens $\dagger$ calls him Wilfrick, and states that he was consecrated Abbot of Ely in 1044. The Register of Ely shows that "he died for grief soon after he had alienated the lands of the monastery." That was in 1066, after he had ruled twenty-two years.

\section{ABBOT LEOFFRICUS.}

Leofric succeeded Arnwig as Abbot of Peterborough, and was nephew of his namesake, the earl. He was also "a man of high birth, and of high spirit." He greatly enriched the monastery with lands and other valuables, and won for it the favour of the king and all the great men of the land. $\mathrm{He}$ ruled that great house thirteen years-from 1053 to 1066.

\section{Abbot Leofstanus}

was surnamed "Plumstan." His name is found among the Abbots of St Albans, he being the twelfth abbot of that celebrated monastery. King Edward and his queen Editha found in Leofstan a "friend, counsellor, and confessor." By

* Phelps' Hist. Somerset, vol. i., p. 527. + Hist. of Mon., vol. i., p. 392. 
means of his great interest at court, he obtained for his monastery, by grant of Oswulth and his wife Adilitha, the farm of Studham; and from Egelwine, and his wife Winefled, the farms of Redburn, Langley Grenebury, and Thwangton.* I presume that he died about the time of the Norman Conquest, as Frederic, the thirteenth abbot, succeeded him in the abbacy of St Albans in 1066.

\section{ABbot ÆLwig.}

Elwig, according to Professor Stubbs, was Abbot of Evesham. I take him to be the same as is mentioned by Dugdale (vol. ii., p. 3), who states that "on King Edward's death he became a favourite with Harold, and was afterwards much esteemed by the Conqueror, by whom he was entrusted with the care of the counties of Worcester, Gloucester, Oxford, Warwick, Hereford, Stafford, and Salop. He died on the I4th of the kalends of March A.D. IO77."

\section{ABBOT HORDORICUS.}

He is sometimes called "Ordric," "Odricus," "Ordricus," or "Hordricus," as in Cott. MSS., Tib. C. ix. He appears as Monk of Abingdon, to which office he was elected in 1052, and which he held till 1065.

\section{AbBot EgELSINUS}

was made Abbot of St Augustine's in 1063 by Pope Alexander II. This abbot is famous in history as being at the head of the Norman army, with Stigand and William the Conqueror, when they came out against the Kentish leaders, at a place called "Swanescompe." They took the duke by surprise, when, like a vast forest, they moved towards him, armed with green boughs, but also furnished with bows and swords, and other weapons, which they concealed. "The duke," says a writer, "was amazed, and in consternation to behold all the country round about him like a moving wood." Finding himself in a difficulty, he speedily

* Clutterbuck's Hist. Herts, vol. i., p. 12. 
granted the people of Kent what they requested. The agreement being signed, and hostages given on both sides, the joyful Kentish men conducted the Normans to Rochester, and there delivered to the duke the county of Kent, with the noble castle of Dover.*

\section{AbBot Lefstanus}

was a monk of Hulm. He accompanied Uvius to Bury St Edmund's, and succeeded him in the abbacy, which he held till August A.D. I065, when he died. $†$

\section{Aвbot EDmund.}

Edmund was the fifth Abbot of Pershore, in Worcestershire, "a person of singular probity, and much respected." His death occurred July I085.

\section{ABbot SiCHTRICUS}

is the last-mentioned abbot on the charter. He occurs as a witness in 1050 to the charter of King Edward, in virtue of which the bishoprics of Cornwall and Devon became united to Exeter. He died on the 8th of the ides of April 1082.

The abbots are followed on the list by the earls.

\section{EARL ELFGAR.}

The third earldom of East Anglia, held at one time by Harold, was bestowed on Ælfgar, the son of Leofric. This occurred circa I053.+ The earldom was soon afterward restored to Harold. The restoration of Harold implied the deposition of Elfgar, whose last recorded acts are the peaceful ones of recommending Wulfstan for the bishopric of Worcester, and of signing the Waltham charter.\$

\section{EARL TOSTIN.}

Tostin, or Tostig, was the third son of Earl Godwine, and

* Steven's Hist. Mon., vol. i., p. 3r4.

† Yates' Hist. of St Edmund's Bury, p. 208. $\quad$ ‡ Saxon Chron., p. 155.

$\S$ Norman Conq. (Freeman), vol. ii., p. 337. 
brother to King Harold. He married Judith, sister of Baldwin of Flanders, and was appointed Earl of the Northumbrians on the death of Siward. But in 1065 he was expelled from his earldom by the Northumbrian thanes. He then went to Flanders for refuge.* "The banished earl crossed over to Baldwine's land, the land of his wife's brother. Under his protection he passed the whole of the winter at St Omer" (1065-66). The "Anglo-Saxon Chronicle" states that he invaded England, and was repulsed by "Eadwine" and "Morkere," and was slain at Stamford Bridge in 1066.

\section{EARL LEFWIN.}

Leofwin, the fifth son of Godwine, and brother to Tostig, sailed with Harold to Bristol, which was a town in Swegen's earldom, then almost unknown to fame. They then went on board Swegen's ship, which speedily carried them to Ireland, where they were favourably received by "Dermot or Diarmid Mac Mael-nambo, King of Dublin and Leinster." Although the two brothers Leofwin and Harold had to seek refuge in Ireland as outlaws, yet they found no place of rest there, consèquently they soon returned to England. When Leofwin became earl, his land extended over parts of "Kent, Essex, Middlesex, Hertford,'Surrey, and probably Buckinghamshire, that is, of the shires round the mouth of the Thames." This is the chief part of his history.

\section{EARL Gyrth.}

Gyrth or Gurth, another brother of Harold, was the fourth son of Earl Godwine. The East Anglian earldom, vacated by the translation of Ælfgar to Mercia, was now conferred on Gyrth (1057-58). In 106I Gyrth, Tostig, and Ealdred, with several noble thanes from Northumberland, went on a pilgrimage to Rome. Gyrth appears as "Eorl" in the Chronicles and "Comes" in Domesday.

The stallers follow next in the charter:

* See an account of Tostig's banishment in Domesday Book, ii. $200 b$. 


\section{ESGARUS.}

Esegar, is noted by Kemble (C.D. 872) as being stallere as early as 1044 - two years, that is, after his grandfather's marriage. He was evidently the son of Æthelstan, and grandson of Tofig.* He appears as "regiæ procurator aulæ," i.e., dapifer in the charter of Waltham, and as staller down to the Conquest. There were several stalleres at one time (A.D. 822). Esegar was a great landholder in the time of King Edward.† "Among inferior dignitaries we are glad," says Mr Freeman, "to recognise Esegar, the descendant of the former lord of the place, who must have looked on the ceremony with mingled feelings." $+\mathrm{He}$ is termed the "procurator of the royal palace."

\section{RODBERTUS.}

Nothing is recorded of him beyond what is stated in the charter-“Rodbertus regis consanguineus." $\mathrm{He}$ is followed by the king's kinsmen and courtiers.

\section{RADULPHUS.}

\section{Bundinus,}

"or Bondig, the staller." He signs the charter as "regis palatinus," the king's courtier.

\section{HESBERNUS}

signs as Rodbertus-“ regis consanguineus," the king's kinsman.

\section{REGENBALDUS}

signs as "regis cancellarus." Mr Stubbs styles him "Rembald the Chancellor, Dean of Cirencester." This person is probably identical with Rumbald the chancellor, who lies buried in the body of Cirencester church. An inscription upon his gravestone states that "Rumbald the chancellor lies

* See Hist. Nor. Conq., vol. i., p. 556 . + De Inv. S. C. W., p. 13.

‡ Trans. Essex Arch. Soc., vol. ii., p. Io. 
buried there." * Regenbaldus, or "Reimbaldus," succeeded Leofric as chancellor. He sealed with the royal seal, as we find by another charter of the Confessor to the church of Westminster thus authenticated. $\dagger$

Petrus, REgis CAPEllanus.

The king's chaplain.

BALDEWIN, REgIS CAPELLANUS.

Another of the king's chaplains. "This name," says $\mathrm{Mr}$ Freeman, "though not unknown in Normandy, is much more characteristically Flemish; and Baldwin was appointed during the time of Harold's greatest ascendancy." He is considered to have been Abbot of St Eadmund's. A Lotharingian prelate of the same name, according to the Anglo-Saxon Chronicle, died A.D. I098. His daughter or niece married Tostig, brother of Harold.

\section{BITHRICUS, PRINCEPS.}

He is called Brihtric, an ealdorman. He was no doubt a "prince." $\mathrm{He}$ may have been the Gloucestershire thane "around whose name a legend has grown in connection with Matilda of Flanders."

ÆLFSTAN, PRINCEPS.-Another ealdorman, or prince.

Wigodus, REgis PINCERNA. - One of the king's cupbearers or stewards.

HERDING, REGINE PINCERNA.-The queen's steward or butler.

ADzUR, REGIS DAPIFER.-Adzur, or Adzurus, is believed to be the same man as appears in Domesday (Berkshire), and who seems to have kept part of his lands as an undertenant at the time of the survey. He signs the charter as a steward, or the king's sewer.

YFING, REGIS DAPIFER.- He is called Yfingus, one of the king's stewards or sewers.

* Atkyns' Hist. Gloucestershire, p. I8o.

+ Campbell, Lives of the Lord Chancellors, vol. i., p. 36 . $\quad$ De Inv. S. C. 
GODWIN, REGINE DAPIFER.-The queen's steward or sewer. DODDO, PRINCEPS.-The prince.

ALFGAR, PRINCEPS.-The prince.

BIXIN, PRINCEPS.-The prince.

EGELNOF, PRINCEPS.-Or Egelnoth. The prince.

ESBEN, PRINCEPS.-Or Esbern. The prince.

EADWIG, PRINCEPS.-The prince.

EDRIC, PRINCEPS. - The prince (or "Eadric the Wild"). He held lands in Hereford and Shropshire (1067-69), and refused submission to William of Normandy, which independence he maintained to the last. The impression which he made on the Normans is shown by the surname of the Wild or Savage which he bore among them. Among the hills and woods of the border land Eadric and his British allies could maintain themselves as easily against the Norman chivalry as Gruffydd had done against the English house earls, till the genius of Harold found out the way to bring the restless enemy to submission."*

EGELMUND, PRINCEPS.-The prince.

SIWARD, PRINCEPS.-The prince.

ALWOLD, PRINCEPS. - The prince.

ELPHIG, PRINCEPS.-The prince.

This ancient manuscript (Cott. Coll., Tib. C. ix.), containing the above list of names, etc., according to the note on the last folio, belonged to the Hill family after the dissolution of Waltham monastery. "George Hilles Boocke" (no date), and "Thomas Hill his Boocke, I6I5," appear with a name written in an earlier hand, but almost erased, the date is plain enough - I 579. The first part of the manuscript on "Vita Ricardi II. per Monach. Evesham et Libertates Eccl. ch. Cant." is less ancient than that on "Registrum Monasterii S. Crucis de Waltham," commencing at folio 48. Folio 233 is the "Rent Roll," given in the "Monasticon."

* See Hist. Nor. Conq., vol. iv., p. I 10. 
The Rent Roll of the Abbey of Waltham at Arlesey, County Bedford.

\section{Firma De Alricheseie.}

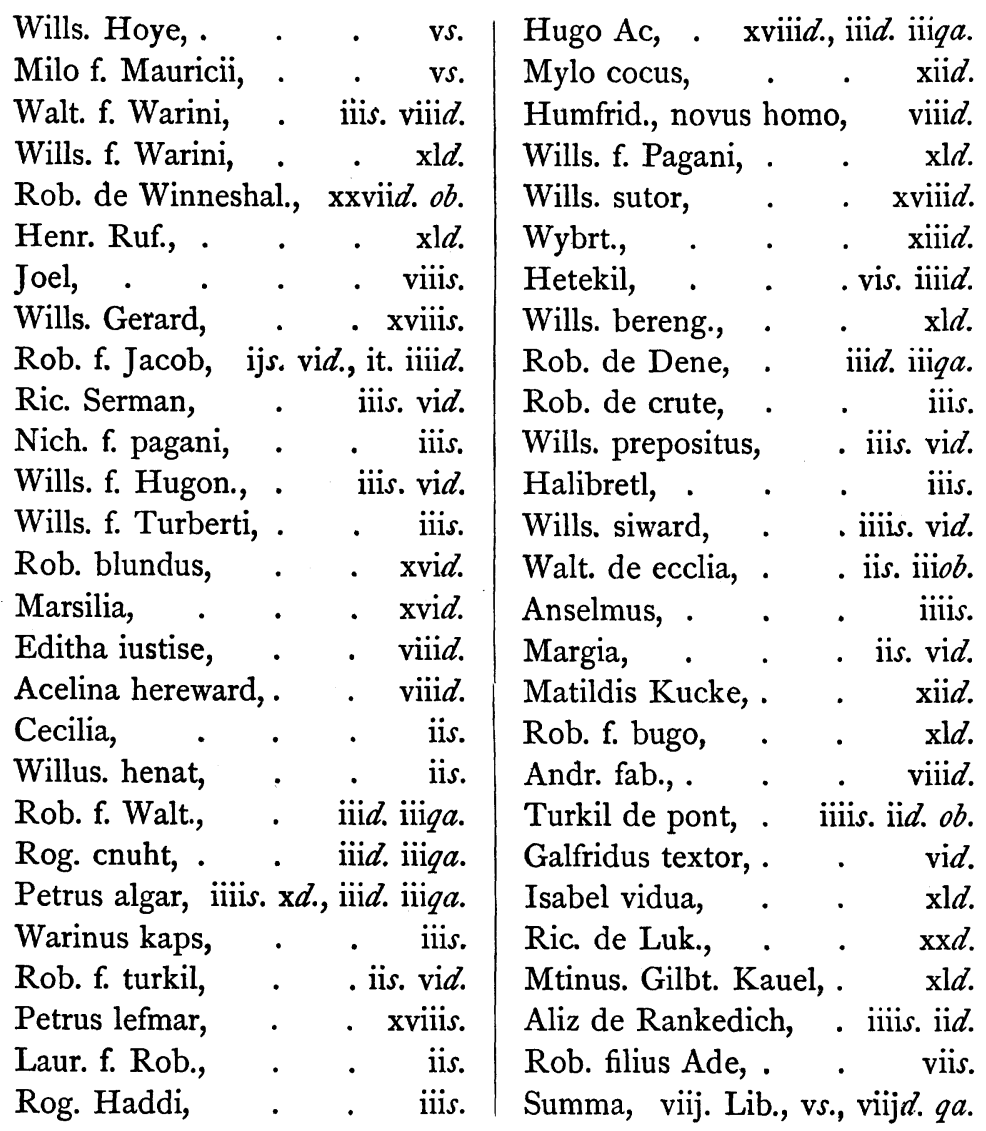

From the Compotus Ministrorum, 32 Hen. VIII.

$$
\begin{array}{rrrr}
\text { Alrychsey-Firma manerii, } & £ 35 & 6 & 8 \\
\text { Perquisita curiæ, } & 3 & \text { I3 } & \circ
\end{array}
$$

The next manuscript for consideration is No. 3776, Harleian Collection. This choice volume once adorned the old Waltham library, and is described by Professor Stubbs as being made some years later than the Cottonian MS. which con- 
tains "De Inventione Sanctæ Crucis." It was the work of a scribe belonging to the abbey, who has interspersed the text with a few lines of original poetry "of infinitesimal value."

The following, written in English, I have discovered (folio 39):

\footnotetext{
"Swete ihu my swete leman : Stedefast loue thou keddest man, tho that blod fram thine bodi ran: so that tou bicome al wan. Swete ihu thou art ful god : for tho thou us boustes onetherod. $\mathrm{Ne}$ schaddest thou naust alitel blod: Ac fra the hit ran as aflod, $\mathrm{Ne}$ seston man hou $\mathrm{i}$ loue the : bidde ich the thou do so me, Ici ye rode ich am for the thou that senegest let for me."
}

The manuscript contains two tracts which illustrate the early history of the abbey. The first is entitled, "Vita et Miracula Haroldi quondam Regis Angliæ." This tract, says $\mathrm{Mr}$ Stubbs, is a curious but entirely untrustworthy legend, written apparently to prove that the great King Harold was not buried at Waltham. The other tract, commencing at folio 25 , is entitled "De Inventione Crucis de Waltham." They are both written in the hand of the twelfth century. The first tract ending at folio 24 is incomplete. It is supposed to have been written by one of the ejected canons, temp. Henry II. At folio 63 is another tract of a still later date, which formerly belonged to Sir William Bowyer (1565). At the end of the volume is an old calendar belonging to John Pim, servant to Mr George Chamberlain. This calendar, as also the "Vita et Miracula Haroldi," is beautifully written with many grotesque capitals, etc.

The Harleian manuscript 3766 bears the following title : "Codicis Rubei Abbatiæ de Waltham Fragmenta Varia." This MS. contains, "Pars Libri cui titulus Liber Niger qui fuit inventus cum Cruce magna de Waltham S. Crucis; et agit praecipue de virtutibus Crucis et miraculis." The whole of the book is written on vellum of the twelfth century, and contains I 6 folios. The tract entitled "De Inventione Sce. Crucis," commences at folio 49 . Folio 25 has suffered much from damp; in other respects it is a very good copy. A great deal of gilt has been lavished on the covers by the binder of a later period. Probably both volumes (3776-3766) 43 
were originally bound together. The date, 30 die Januarii I $72 \mathrm{I}-2$, on the first folio, is in the hand of some late owner of the book. The Cottonian MS., Claud. D. II., is a most splendid manuscript. Its illuminations are of a very superior character. Folio I $4 b$ contains a transcript of the foundation charter of Waltham, which occupies only about five and a quarter columns-most likely it was written by a Waltham monk and once belonged to the abbey. In I 598 it belonged to Robert Cotton.

Julius D. vi. is another MS. formerly in the possession of the above-named gentleman. It contains the "De Inventione et Miraculis S. Crucis de Waltham," which commences at folio 75. The first part of the MS. is entitled "Suppletio Historiæ Regum Angliæ ad ann. I216 per John Pike," and the part referable to Waltham was collated with and corrected by the Harleian copy 3776 , both of which are no doubt copies from one original. The first of these two (Jul. D. vi.) is thought to be not much later than the date of the original composition. A transcript of this MS. is given in the "Miscellanea Historicana Anglicana," vol. i., fol. I, xxxviii., Harl. MSS. 692, under this head-“De initio et fundatione Ecclesiæ de Waltham, ex antiquo Codice Bibliothecæ Cottonianæ, qui inscribitur Jul. D. 6."

Harleian MS. 4809 is one of two original registers on vellum, which, I presume, were also kept in the library of the monastery of Waltham. This fine cartulary was originally divided into twenty-one sections, each containing the charter of a manor; but now it begins with the seventh, and that relating to Alricheseye is wanting. This defect will be in great measure supplied by the following charters, which are arranged according to the numbers of their monastic endorsements.* This MS. is fairly written, and consists of 194 double pages entitled "Registrum Cartarum Abbatiæ Waltham Com. Essex." It formerly belonged to Sir William Heyward of Loughton, whose autograph appears on the front page, and was subsequently in the possession of Peter le Neve, Esq.,

* See Collectanea, vol. vi., p. 196 ; also Harl. MS. 391. 
Norroy King of Arms. The first and last page contains his name, dated respectively I7OI and 24th September I703. This MS. appears to have been written in the fourteenth century, and records the great possessions belonging to the abbey.

Harleian MS. 39I is the other register on vellum of very early date, which was at one time in the possession of Peter le Neve, Esq., as is recorded on the flyleaf, "Liber Petri Leneve Rouge crux Prosecutoris armos anno sedum computationem anglicanam 1698, quondam Liber Willi Hayward militis Pretrum £I, IOs." This MS. presents us with several charters, in which Henry is designated by his brother Richard and by his mother Queen Eleanor as Henry III. These charters are in confirmation of the abbey's change of its inhabitants. A charter of the first Richard confirms its possessions to the abbey, as also one by Queen Eleanor granted by her in Richard's time. Here also is a charter from Henry acknowledged in our histories as the real Henry III. to the same monastery. ${ }^{*}$ This ancient volume was purchased by James West, Esq., but whether for himself or Lord Oxford is not certain; it is thought for the latter, because in the printed catalogues of that lord's MSS., No. 39I is found "Registrum Abb. Waltham, bought at $\mathrm{Mr}$. Norroy's sale." In Le Neve's catalogue, printed in I730-I, there are entries of several registers, charters, etc., of different places, among which occurs one, "No. I38, Chartularium Abbatiæ in com. Essex, written on vellum, very fair, $£ 7$, 8s." $\dagger$ This the writer has identified as being the identical book now the subject of consideration. This volume commences with a rubric expressing "de aquæductu de Wirmele ad Waltham," annexed to which is the date, M.CC.XX. (1220). From the first few pages of the MS. we learn that at this early period there were artificial waters connected with the Abbey of Waltham, which extended to Cheshunt and Wormley. On folio 6 there are three foun-

* See Johannes de Oxenedes Chronica (Ellis), I859, pp. xxi., xxii.

† Nichol's Lit. Anec. of Eighteenth Century, vol. ix., p. 421. 
tains, two of which take their rise north and south. The southern fountain appears to be at Cheshunt; the northern probably at Wormley. These two fountains emptied themselves into an eastern pool, right of which is another fountain; the situation of this may have been at the nunnery of Cheshunt, which stands on the right hand leading from Wormley to Cheshunt. A main water pipe-calamus-connected with this pool or tank, carried the water through a bed of clay-argilla-in an easterly direction towards a great fish pool-piscina-which had two outlets or pipes. The one appears to have carried off the waste water, the other was used for washing or cleansing purposes-cal. purg.-etc. Another pipe leading from the fish pool was for the use of the inhabitants of Waltham.

The Abbot of Waltham, Lord of the Manor of Wormley, sent annually to the cross erected at Wormley west end some of his canons, who on the $3 \mathrm{~d}$ of May and $14^{\text {th }}$ of September walked in solemn procession with the parishioners singing the Litany. The place retains the name of Holy Cross. This seems to be a kind of processioning to keep their lands that join to the kingdoms of Mercia distinct from the lands of the Abbey of St Albans which were in that kingdom and contiguous to Wormley.* This Benedictine house at Cheshunt is mentioned in a bull issued by Pope Lucius III., bearing date I $5 \mathrm{kal}$. Jan. I 83 , among sundry other privileges which exempted the site of this house with all the lands, tenements, etc., belonging, from the payment of tithes. So that we may certainly date the foundation of the house before that year. In the 24th Henry III., I240, the possession of the nuns of Cheshunt were augmented with lands belonging to the canons of Cathall, who appear to have been removed by the king. $\dagger$

The transcript of the fountains is followed by a memorandum respecting the marshes of Waltham and Cheshunt"Hic pmo. Orit Clanicio marisce pea. Villanos de Chesthunt," dated anno. dom. I200. At folio 13 is a transcript of the

* Salmon's Hist. Herts, p. I4. + Monasticon, vol. iv., p. 328 . 
charter of Wormley. This manor was one of those lordships given by Harold to the church of Waltham. Upon a Quo Warranto taken in the sixth year of the reign of Edward I. before John de Reygate and others, the king's justices itinerant for the county of Hertford, the Abbot of Waltham claimed certain privileges in this and other manors, which were allowed. The canons continued to hold this manor until the dissolution, when it was seized by the Crown.* On the same folio (I3) is a "Transcripta Cartarum de fonte uro. de Wermele." By charter Henry, son of William of Wormley, grants to the church of Waltham in pure alms one piece of land in the ward of Wormley and all his fountains. Folio 14b.-The charter of Richard and the cupbearer of Wormley-Ric. de pincne. de Wermel-grants to the same church and canons the right of the fishery in Wormley. Folio 15 is the charter of John de Stinekle, fil. Willi of Brokesburn, by which he grants to the church of Waltham in pure alms an acre of land and a fountain in Wormley. Also the charter of Alexander de Poyntun. Folio 16 is the charter of Henry de Kersebrok of Cheshunt (i.e., Crossbrook), and Will fil Alwyn, a miller of Waltham. Also the charter of Thomas de Haverell and Walter de Hale, granting small donations to the church of Waltham. Folio $I 7$ is the charter of Ricard Hok, granting the rights of commonage in "Hokesmerst" to the canons of Waltham in pure and perpetual charity. The name of Richard Hok gave rise to the name of the marsh in Waltham, "Hooksmarsh," known as such in the present day. Folio I $7 b$ is the charter of Nicholas the clerk, the son of Walter the forester of Waltham, by which he grants in pure alms his right without impediments in Colberdesholm, etc., to the said canons of Waltham. Folio I 8 is the charter of William Portingale, by which he grants to the canons of Waltham his meadow situated at Frithey near Hokesmers, and also a conduit for washing-vsu expurgatorum aqueductis. Folio 23 gives the return of the clear amount of the revenue of the Abbey of Waltham, bearing date 1266. 
In Dioc. London.

De Manerio de Waltham,

De Eccl. de Waltham, . . $\quad \begin{array}{llll}33 & 6 & 8\end{array}$

De Sywardestune, . I3 3 ○

De Nasinge, . • 28 ○

Quia de eodem manerio solvuntur, . $20 \quad 0$

Ad firmam Dm. Reg.

de Eccl., . $\quad$. 6 I3 4

De Eppinge, . . $14 \circ$

Q. de eodem, . . 2000

Ad firmam Dm. Reg.

computant.de Eccl.

eidem, . . Iо $\circ \circ$

De Stanstede, . $\quad$ I I 990

De Netleswell, . Iо 0 I I

De Passefeud, . 13 I5 2

De Borham, . . I 0 o

De Stanweye, . $\quad$. $\quad$ I $44 \quad 4$

De Redditu in Lond., I3 3

De Takeleya, . $\quad 5 \quad 5 \quad 0$

De Stanforde, . 8 ○ 0

De Thorendune, . 9 I8 0

De Walda, . . I I 15 I I

De Upmenstre, . 7 I 7 ०

De Luketune, . II 2 ○

De Wudeford, . 5 I4 I I

De Wrmeleya, . 4 r6 8

Suma, . $\overline{£ 2 \text { Iо I7 } 3}$

Sa. Decimæ, $£_{2}$ I I ro*

Folios $19 b$ and $20 b$ are a list of the holders of capital messuages in Waltham Holy Cross, temp. Henry II.- "Hec sunt Capit. Mesuagia integ. Sce. crucis de Waltham."

The list of these local men and their houses is somewhat interesting. No doubt they composed the major part, if not all, the population of Waltham Abbey, in the reign of King Henry II., circa I I 54-I I 89:

Mesuage. Walti. de Eldewirche, diuise. $\dagger$ in ix. ptib. John Gladewine, Wills. Sunel - thurstan, Elyas Goding. Sunel man, Rob. Joiberd, S. de Walda, R. de occident. It. Joh. Gladewine.
Mesuagui. Thom. Beneit, dns. Mesuag. Ric. Pistoris, integ. Mesuag. Stephi. Beneit, integ. Mesuag. Ysaac Pistoris, integ. Mesuag. Nichi. fil. Willi., integer.

Mesuag. Johis. Sute, dns. in ij. Mesuag. Ric. Tanacoris, integ. Mes. . Benedicti fulms, integ.

* This is printed in the Transactions of the Essex Arch. Soc., vol. iii., part ii., p. 35 .

+ Divided into nine parts. 
Mes. . $\begin{gathered}\text { Benedicti Tanacor, } \\ \text { integ. }\end{gathered}$

Mesuag. buriom, integ.

Mes. . Ric. lauret, integ.

Mes. . Rad. Taunator, integ.

Mesuag. Ric. fros., integ.

Mesuag. Walti. Orglen, integ.

Mes. . Galfr. fros., integ.

Mes. . Walti. tholom, integ.

Mes. . Humfridi fil. Ric., integ.

Mes. . Wakerild, integer.

Mesuag. stori., integ.

Mes. . Elye carbunel, integ.

Mesuag. Magri. Vnilli, integ.

Mesuag. Clauham, integ.

Mesuag. Gunnild orglen, integ.

Mesuag. Arnoldi fabri, integ.

Mesuag. Joye, integ.

Mes. . Ade fil. Benedicti, integ.

Mes. . Willi. everard, integ.

Mes. . Henr. fil. Jacobi, integ.

It. Mes. Magri. Willi., integ.

Mes. . Willi. langsuem, integ.

Mes. . luuekin dulpain, integ.

Mesuag. buckesberd, integ.

Mes. . Wækoc, integ.

Mes. . Henr. Sad, integ.

It. Mes. ide. H. M., integ.

Mes. . Aluene, Rob., integ.

Mes. . Willi. Molend, integ.

Mes. . husser, integ.

Mes. . Symois. de bosco, integ.

Mes. . Rad. le Brun, integ.

Mes. . Galien, integ.

Mes. . Johis. Russel, integ.

Mes. . Wækoc, integ.
Mes. . Henr. Sad, integ.

Mes. . Willi. Sudkin, integ.

Mesuag. Walti. pistoris, integ.

Mes. . GoduuiniSpling,integ.

Mes. . Buteslie, integ.

Mesuag. Walti. de eldenviche, integ.

Mes. . Thome le Messer, integ.

Mes. . Alam Brunig, integ.

Mes. . Walti. de Bosco, integ.

Mes. . Thom.Parmitar,integ.

Mes. . Ric. Kinu., integ.

Mes. . Willi. de Marisco, integ.

Mes. . Robi. Pistoris, integ.

Mes. . Johis. curiol, integ.

Mesuag. Godeholt, integ.

Mes. . Hardwini spith., integ.

Mes. . Pet. de sarcno, integ.

Mes. . Stephi. Grim., integ.

Mes. . Galfri. dulpain, integ.

Mes. . Stephi. Batle, integ.

Mes. . Hug. faful, integ.

Mes. . Moysi. doy, integ.

Mes. . Sunois frere, integ.

Mes. . Willi. Godefrei, integ.

Mes. . Walti. le gaunt, integ.

Mes. . Wymudi fabri, integ.

Mes. . Bubo, integ.

Mes. . Willi. cardun, integ.

Mes. . Thome Nuttis, integ.

Mes. . Peketo, integ.

Mes. . Clauham, integ.

Mes. . Milonis coci, integ.

Mes. . Johis. lel., integ.

Mes. . Alam Brunig, integ.

Mes. . fot., integ.

Mes. . Rogi. fabri, integ. 
Mes. . Joci. fabri, integ.

Mesuagui. Gayole, integ.

Mes. . Ric. faful, integ.

Mes. . Willi. estinar, integ.

Mes. . Johis. de Marisco, integ.

It. ide. . Altu. mes., integ.

Mes. . Willi. Horgor, integ.

Mes. . Marcelli cissoris, integ.

Mes. . clauham, integ.

Hec sut. diuisa.

Mes. Robti. molend, dns. in j. Mes. Alex. Sat, dns. in . ij. Mes. Cadema, d. in . . ij. Mes. Vault de Ponte, d. in ij. Mes. Thom. Schibet, d. in j. Mes. Alam Brunig, d. i. . j. Mes. Rob. laur., d. i.

Mes. Rob. Mcator., d. i. . j. Mes. Alam fullonis, d. i. . ij. Mes. Paulini, d. in . . iij. Mes. Ric. fil. Galfr., d. in . ij. Mes. Willi. Dyomsu, in . j. Mes. Ric. terling, d. in . j. Mes. Willi. de Ware, d. in. j. Mes. Willi. cissoris, d. in . j. Mes. Pet. Marcelli, d. i. . j. Mes. ad. cemtar, d. i. . j. Mes. Alex. Bucke, dns. in. j. Mes. Norme, d. in . . iiij. Mes. Isabell.Langfuein, d.i. j. Mes. Rad. Pannar, d. in . ij. Mes. Benedicti furley, d. in $j$. Mes. Gilebti fil. Rikild, d. i. ij. Mes. Rad. Pictoris, d. in . ij. Mes. G. luce, d. in . . j.
Mes. Johis. de baudac, d. i. j. Mes. Walt. Palent, d. i. . iiij. Mes. Olivi, d. i. . . iij. Mes. Laur. estmar, d. i. . ij. Mes. Ric. Babbe, d. i. . ij. Mes. Ric. flur., d. i. . . ij. Mes. Willi. Portaru, d. i. . ij. Mes. Augtnu. Godard, d. in ij. Mes. Rob.deWermele, d. in ij. Mes. Aldwyn Puge, d. in . j. Mes. Rad. de infirmar, d. i. j. Mes. Hug. Sarrator, d. i. . j. Mes. Nich. cemtar, d. i. . ij. Mes. Ric. Cat., d. in. . j. Mes. Henr. Sculle, d. i. . j. Mes. Roc., d. in. . . j. Mes. Coti., d. in. . . v. Mes. Aylumdi, d. in . . j. Mes. Rob. de Epp, d. in . ij. Mes. Walti. Cissoris, d. i. . j. Mes. Stephi. Grun, d. i. . j. Mes. Rogi. nucu, d. i. . j. Mes. Prur, d. i. . . , j. Mes. Robti. Suite, d. i. . j. Mes. bndicti. fermin, d. i. . j. Mes. Bulge, d. i. . . j. Mes. Rad. Polisur, d. i. . ij. Mes. Ric. hunfrey, d. i. - iij. Mes. Walt. Orglen, d. i. . ij. Mes. Matild. Mayngod, d. i. j. Mes. Johis. Marescalli, d. in j. Mes. Henr. beusche, d. in j. Mes. Henr. Gos., d. in . j. Mes. Thome Nutcis, d. i. . j. Mes. Johis. Berd, d. i. . j. Mes. Clemtis. bigge, d. i. . j. Mes. Walti. Lithfot, d. i. . j. Mes. Johis. Roc, d. in . iij. Mes. Gulot, d. in . . j. 
Mes. Kipping, d. i. . . iiij. $\mid$ Mes. Maur. ppositi, d. i. . j. Mes. Stephi. babbe, d. i. . iij. Mes. Johis. Gos, d. i. . iij. Mes. Xpian. terttis, d. i. . j. Mes. Edwardi Sabarn, d. i. ij. Mes. Edith. ful., d. i. , j. Mes. Henr. de farto, d. i. j. Mes. Gunnore, d. in . . j. Mes. Hay, d. i. . . j. Mes. Matild. Samuel, d. i. ij. Mes. Math. Ps., d. i. . j. Mes. Ric. Gatle, d. i. . j. Mes. Robti. fabri, d. i. . j. Mes. Dile, d. i. . . j. Mes. Sawile de budeshath, d. i. . . . j. Mes. Osebti caretarii, d. i. j. Mes. Willi. Jacob, d. i. . j. Mes. Galfr. frohs, d. i. . j. Mes. Gunild. leskem Milessot, d. . . . v.

Folio 29 is an indenture made between Robert de Vere, Earl of Oxford, and Alice, his wife, on the one part, and the Abbot of Waltham on the other part, dated Westminster, "Sci. Johis. Baptiste Anno Regni Regis Edwardi sexto" (6 Ed. I., I278).

The said Robert de Vere, and Alice, his wife, petitioned the Abbot of Waltham for the manor of "Sywardstone" (Sewardstone), which was held by their father of the king in capite- " Robts. de Ver comes Oxonis \& Alic. ux. eius petuat rd. Abbem de Walthen Manur. de Sywardiston cu. ptinent. vt jus ipsius Alicie P. Pape in capite," etc.

This was Robert de Vere, fifth Earl of Oxford, who married Alice, daughter of Gilbert, Lord Sandford, chamberlain to Queen Eleanor, and sister and sole heir of Nicholas, Lord Sandford.

Robert died 24 Edward I., A.D. 1295. Alice died at Canfield House, near Dunmow, the 9th September 1312. This Robert was one of the barons in arms against the king.

Folio $30 b$ is a charter of Henry II. to Richard Fitz Aucher of Copped Hall, in which the king grants and confirms to the said Richard two pieces of land-duas vgatas terre-called "le Poer," in Waltham, with an additional two acres of assart land-a clear place in a wood-for the erection of a mansion with the privileges and rights of all surrounding woods, lands, pastures, waters, mills, etc.

Folio $3 \mathrm{I} b$ is an order, or as the margin states, "discharge from the king (Edward I.), to pay the rent of the manor of 
Waltham, to Alinore the queen," daughter of Ferdinand III., King of Castile, the first wife of King Edward I.

Annexed to this is the "like warrant, the baroons of the echeccur, and the discharg of the Abot of Waltham," A.D. I28I.

Folio 33 gives the ancient charter of Edward the Confessor, which is printed in the "Monasticon," vol. vi., pt. i., p. 6I. Here also are the charters of Henry II., Henry III., Richard I., Queen Alineor, and King John.

Folio $48 b$ commences the grants which Queen Alienor confirmed to the canons of Waltham.

Folio 50 is the following note in English, written early in the sixteenth century :

"Be the Duk of Gloucestre, chef iustice of all the fforest a this half trent, for as muche as we be enformed that ye purpose to malynge agenst the libertes \& ryghtes grawntyd be my lordis noble pgenitours to ye Abbot \& convent of Walthm, \& by my seyd lord satyfied \& confermed, by undue meenes agenist trouth \& gode conscience; we wele \& charge you to cesse of your malice, and from thns forth to suffre hem, theyre suants, fermoures \& tenants, thar godis \& catall, to sem rest, \& in nowyse agenst hem nor non of hem t'attempte, but hem godly cherisshe in thar ryght, and to charge alle offices of yt forest to do ye same, $\&$ in no wyse to doo ne $y^{t}$ to doo ye cont'ry offer as in you is, as we trust you. And as ye will have our gode lordship and eschue ye rens as the cas requireth yeu en."

Folio 57 is a charter of Simon, Abbot of Waltham, to Stephen Fitz Aucher, of all the land in "Kingestanfare," in Waltham, temp. Henry III., dated at Waltham on the Feast of St Dunstan, A.D. I270.

Folio $7 \mathrm{I}$ is the "Cirographum int. Dnm. Abbem de Waltham et Dnm. Petru de Sacbadia." This is relating to the grievance between the two parishes, Waltham and Cheshunt- "Hec est finalis cocordia. facta in curid. dni. Regio apud Westmons. a die Sci. Anchaelis in tres septinanas anno Regio Regis Henrici filii Regis Johannes tricesimotcio" (folio 7I). This is followed (folio $74 b$ ) by "the bowndys bytwen the lordshippys of Walthm and Chesthunt;". also a charter of King Henry III., 
by which he grants to the canons of Waltham lands in Nazing, Epping, Loughton, and Woodford. Folio 77 gives the "Prima Carta Michaelis de Wanci de Stanstede* qam. fecit nob. tepore. Regis Henrici II. adwocati uri. Scdam. Inwernes carta pdci. militis de pdca. uilla i. sequta, folio ix." This relates to the manor of Stanstead, county Herts. Michaelis de Wanci in the time of Henry II. was lord of the manor of Stanstead. The charter (folio 77) expresses that the said Michael sold one moiety of his manor to King Henry II., who thereupon acquitted him against ("Bruno iudeo de London") Bruno the Jew of London of a debt of $£ 280$, I7s. 3d. The said king afterwards gave this moiety to the canons of the church of Waltham.

The other moiety the said Michael gave to the canons of Waltham (in the presence of the king) in perpetual alms, to hold of him and his heirs by the yearly rental of $£ \mathrm{I} 2$, with all covenants and liberties made between them, free from all

* Richard I. compelled the Abbot of Waltham to restore to Walter Peterin three messuages in Standstead, of which he had been unjustly deprived; from which we may infer that the entire manor did not at that time belong to the abbey. Another circumstance goes to prove that the Abbot of Waltham did not obtain permission to enclose the wood of Isneye and empark it until the time of Edward III. John, the Abbot of Waltham, granted by lease, dated November 7 th, 1523, the manor of Stanstead to John Rodes of London, and Margaret his wife, for a term of sixty-one years, at the yearly rental of $£ 25,6 \mathrm{~s}$. 8d. He only remained in possession nineteen years, for at the dissolution of the abbey the manor was seized by the Crown and conveyed to Philip Paris.

The old manor-house of Stanstead near the church, now in the occupation of Captain Trower, stands within the limits of what was undoubtedly a Roman encampment. The mound by which it is surrounded, the fosse, its advantageous position commanding the valley of the Rye, its very name Stansteadbury or burgh, indicate that a fortress formerly stood upon its site. In later years it was a grange belonging to the Abbey of Waltham. In a wall in one of the cellars were recently discovered two niches; one is a piscina, the other, which has no drain hole, was probably intended as a locker or ambrey. This was then a chapel; and the discovery of the niches shows that a square recess in the east wall was designed to receive the altar. That the Abbots of Waltham should make choice of a damp, underground cellar, not ten feet square, for a chapel, into which a ray of light never entered, cannot be supposed. It was undoubtedly constructed after the suppression of religious houses, when it was dangerous to openly practise the rites of the Romish Church (Cussan's Hist. Herts, and Chauncy's Hist. Herts). 
royal and foreign service. At the time when these donations were given to the canons of Waltham, Gilbert de Strigul was in the custody of King Henry II. These gifts were afterwards confirmed by William Mareschal (see folio 87 of the same MS.), who married the heiress of Gilbert de Strigul. Richard I., by a grant dated I8th September in the tenth year of his reign, confirmed these donations, expressly declaring that although Gilbert de Strigul was in the custody of the king's father at the time when they were made, yet because they were with the authority and knowledge of a wise and venerable prince, and not without great counsel, therefore the successors of Gilbert de Strigul, whosoever they might be, should not be admitted to controvert the donations. The Abbot of Waltham claimed by the grant of King Edward I. soc, sac, toll, them, infangtheif, flemensfrith, grithbrick, forstal, homsocne, bladwite, ordel, oreste, and easement from shires, hundreds, and from the court of the Holy Cross, and from all pleas, taxes, tolls, etc. (by the grant of King Henry II.), in all their lands in this county, i.e., Wormley, Brickendon, and Stanstead; and all liberties which kingly power could grant to any church, from the passage over bridges, and from all works, etc., chattels of felons and fugitives, year and waste, custody of men taking plea of namium vetitum, free fishing in the water of the sea, to make pools, etc. Free warren and waifs by the grants of King Richard I. and Henry III. upon quo warranto brought before John de Reygate and others, justices itinerants at Hertford, anno 6 Edward I., they were allowed.*

In the MS. now under consideration (Harl. 39I), together with the Tib. C. ix. already noticed, is found a series of fifteen charters relating to Alricheseia, county Bedford. An account of some of these is given by Stacey Grimaldi, Esq., F.S.A., from the originals in his own possession. $†$ The fifteen numbers or charters just mentioned answer to the endorsements on Mr Grimaldi's deeds, Nos. VI. to XI., XIV.

* See Chauncy's Hist. Herts, p. 192.

† Collectanea Topog. et Geneal., vol. vi., p. 196. 
and XV.; they also supply the deficient Nos. I. to V. and XIII., and they furnish a different No. XII. The chartulary of the Abbot Fuller, now in the Harl. MS. 3739, has been examined, but no charters regarding lands at Alrichesey occur therein.

Alriches, or Alrichesey as it is sometimes written, belonged to the church of Waltham from the earliest times. It occurs in the confirmation charter of Edward the Confessor"Alricheseia cum omnibus ad se pertinentibus." Alrichesia is situated about three miles south-east of Shefford, in the hundred of Clifton. It was formerly a market town, which is so stated in Domesday. In I270 it was confirmed to Stephen Edworth, then lord of the manor. The De la Poles possessed the manor in the reign of Edward III. In the reign of Henry VIII. it was held by the Tanfields under the Earl of Shewsbury.

The great tithes of the parish, which were appropriated to the Abbey of Waltham, were the property of the late Mrs Schutz, daughter to $\mathrm{Dr}$ Browne, in whose family they have been vested for many years. ${ }^{*}$ Domesday Survey expresses that Alrichesia, which was estimated as eight hides, was temporarily alienated to the Bishop of Durham. Some of the grants are very curious, viz.:

“Terra epi. Dunelm'sis. In Hund. de Clistone tenisd. eps. viii. hid. in Alricesei 7 ii. part. i. virg. T'ra e. viii. car. In dnio. sunt iii. car. 7 viii. villi hnt. iiii. car. 7 vta. pot. fieri. Ibi. v. bord. 7 ii. servi. 7 ii. molini xxvi. solid. 7 viii. den. Patu. iii. car. Valet et valuit vii. lib. T. R. E. viii. lib. Hoc. M. tenuer. canonici St. Crucis de Waltha. in elemosina T. R. E."

The manor of Alrichesia held by the Abbot of Waltham was then only reckoned as three hides:

“Aylricheseye.-Abb. de Wanth'm. iij hydas in capite de d'no. Rege in pura elem."

There is in the Waltham charters much relating to the estates as well as to the genealogy of the Burnard family,

* Lyson's Hist. Bedfordshire, p. 40. 
which family chose the Priory of St Neot's, Huntingdonshire, to be their burial-place.

There are also several other charters given in this MS. (Harl. 39I) worthy of notice. "Carta balfrida de Melno" is one of them. The manor of Milno (now called Millow or Milhow) is a hamlet in the parish of Dunton, county Bedfordshire. King Edward the Confessor gave it to the church of Waltham.

"Carta terra in Pochia. Sci. Clementis London." This is a grant of a portion of land in St Clement's parish to Walter, Abbot of Waltham.

"Carta terra in Emwelle" (Amwell). This manor is situated in the parish of All Saints, Hertford, and is called Rushen, otherwise Little Amwell. It probably formed part of the manor of Brickendon, in the same parish, which at the time of the survey was parcel of the demesnes of the canons of Waltham. This place was the property of the canons of Waltham, 6 Edward III., when they had a grant of free warren in Brykendon Emwell.

The canons of Waltham also had the patronage of the Church of All Saints, Hertford, prior to the dissolution of monasteries.*

Folio $84 b$ of this MS. gives the charter of Robert de Valonsis of the Church of All Saints, Hertford. Robert de Valoignes, for the health of himself and Hawise his wife, gave the Church of All Saints in Hertford to the canons of Waltham. Folio $87 b$ is the "Carta Gilebti filii Walielmi de Windlesores." Folio 97 is the "Confirmatio Jocelim Saresbiriensis episcopi de Ecclesiis de Windesore." This appears to be a grant of confirmation by Josceline, Bishop of Salisbury, who was consecrated in $\mathrm{II}_{4} 2$. He is called "Josceline de Bailol, a Lombard," and was archdeacon of Winchester, afterwards prebend of York, and died I I 84 . He was one of the bishops excommunicated by Becket in II66 and II70 for consenting to the coronation of the younger Henry. Josceline had a son named Fitzjosceline.

* See Clutterbuck's Hist. Herts, vol. ii., p. 182. 
This grant of Josceline refers to the church of Windsor, and also to a dispute which seems to have arisen between Roger le Poer, the predecessor of Josceline, and the Archbishop of Canterbury, respecting the castle of Windsor, which dispute delayed the marriage of King Henry and his second queen, Alice or Adelicia, the beautiful daughter of Godfrey of Lorraine. The Bishop of Salisbury claimed a right to marry the royal pair, because the castle of Windsor was within his diocese. The right was disputed by Ralph, the Archbishop of Canterbury, on the ground that, whenever the king and queen might be within the realm of England, they were his parishioners. The ceremony was eventually performed by the primate, on the 24th of January II 2 , in the presence of the whole council of England, then assembled at Windsor.*

By this grant of Josceline's it would appear that the canons of Waltham had possessions in Windsor prior to Richard I. (I I 89-90). $\uparrow$ This king, however, in the first year of his reign, gave the Church of St John the Baptist, New Windsor, with the chapels of Old Windsor, to the canons of Waltham, in whose possession it remained until the dissolution.

Among the appendages to the castle at this period (I9 Henry II.) was the vineyard. The pay of the vintager and the expenses of gathering the grapes are among the regular annual charges relating to Windsor on the Pipe Rolls, from the commencement of the series in I155. Lambarde says, in the "Recordes," "it moreover appearethe that tythe hathe bene payed of wyne pressed out of grapes that grewe in the Little Parke theare, to the Abbot of Waltham, which was parson bothe of the Old and New Wyndsore, and that accompts have bene made of the charges of planting the vines that grewe in the saide parke, as also of making the wynes, whearof somme partes weare spent in the householde, and somme solde for the kinge's profite." Stow gives a similar account. He says that in the records of the Honor Court of Windsor Castle, held in the outer gatehouse, is to be "seene

* Tighe \& Davis' Annals of Windsor, vol. i., p. 28.

+ See Cott. MS., c. ix., folio 62 ; Harl. 391, folio 97. 
the yeerely account of the charges of the planting of the vines that in the time of $\mathrm{K}$. Richard the Second grew in great plenty within ye Litle Parke, as also of the making of the wine itself." Richard III., in the first year of his reign, granted to John Piers the office of "Master of our Vyneyarde or Vynes nigh unto our Castell of Wyndesore, and otherwise called the office of Keeper of our Gardyne called the Vyneyarde nigh unto our said Castell, to have and occupie the same office, by him or his deputie sufficient for the terme of his lyff, with the wages and fees of vid. by the day." *

King Henry III., in the eleventh year of his reign, confirmed by charter the church of Windsor to the canons of Waltham, at which time the canon complained that, "although his tenants of the property of Windsor church had always been exempt from tallage or taxes, yet that the king's officers of the Exchequer had assessed them in common with the other inhabitants of Windsor, and refused to make restitution. The king thereupon directed inquiry to be made into the truth of the abbot's allegation of previous exemption, and commanding that, if found to be true, the tenants should be exempt from payment." $†$ Pope Nicholas IV., in the year I288, granted to King Edward I. the tenths of all ecclesiastical benefices for the term of six years, in order to defray the expense of a journey to the Holy Land. The king's taxes which began in that year ended in I29I. "Under this taxation, New Windsor is inserted in the diocese of Salisbury. . . . The Abbot of Waltham was, in the first instance, assessed at 3s. 2d. in respect of New Windsor, and at $12 \mathrm{~s}$. $8 \mathrm{~d}$. in respect of Old Windsor; but a line is drawn across both entries. "Wyndlesore Underore" is described as being (with several other places) in the hands of the Reading Abbots. In the "spiritualities" of the deanery, Windsor Church is not mentioned by name, but the church of Waltham Abbey, with the vicarage, in respect of tithes, is assessed at $£ 13,6 \mathrm{~s}$. 8d., referring probably to the churches of Old and New Windsor, both

\footnotetext{
* Annals of Windsor (as before), also Lambard's Dict. Angliæ. $\quad+16$.
} 
of which were, as has been already stated, in the possession of the abbey.

King Harold previously held the manor of Windsor, which, in his time, comprised but five hides and a half, the castle of Windsor being erected on the other half hide.

In this MS. (Harl. 39I) there are several charters relating to lands in London. Folio $89 b$ is the charter of William Revel (and Andrew his heir), by which he claims certain liberties of "Ricard. filii Ernaldi," the Abbot of Waltham. The Revel family were of considerable note in their time. A John Revel held the manor of Revel's Hall in the vill of Bengeo, county Herts, temp. Henry II.* Robert Revel was one of the sheriffs of London, I490. He gave liberally towards the rebuilding of the Church of St Mary-at-Hill, London, where he was buried. $\uparrow$ This church is so called from its being dedicated to the Virgin Mary, and its situation on an eminence. In digging the foundation of the present building in 1497 , the corpse of Alice Hackney, who died about the year 1322, was discovered in a very decayed coffin. The skin of the corpse "was sound and flexible, and the joints pliable, though buried about 175 years. The body was kept above ground three or four days without any noisome smell, but then, beginning to be tainted, was again laid in the ground." $\ddagger$

Folio 90.- "Carta Scotlandi de Yfeld de loco \& tra edificion uron in londoniis." This deed or charter (like several others given in this volume, is without date) has been fully described by G. R. Corner, Esq., F.S.A., in a letter to Sir Henry Ellis, under the title of "The Abbot of Waltham's House in the Parish of St Mary-at-Hill, London," published in the "Archæologia," vol. xxxvi., p. 400 . "It is remarkable," says the writer, "that Stow makes no mention of the Abbot of Waltham's house at St Mary-at-Hill, although the industrious London historian lived hard by, in the parish of St Andrew's Undershaft. . . . St Mary-at-Hill is a street running north and south from East-

* Clutterbuck, vol. ii., p. 28.

† Stow's Survey, and Malcolm's Londinium Rediv., vol, iv., p. 422.

$\ddagger$ Chamberlain's Hist. Lond., 459. 
cheap to Billingsgate, and at a short distance on the west is a narrow lane called Love Lane, one of the narrowest and most crooked lanes in the city of London, running from Eastcheap to Thames Street. The parish church of St Mary-atHill stands between these two ways, and the Abbot of Waltham's house stood on the south side of the church, towards Billingsgate. Walter de Gaunt, the first Abbot of Waltham, became possessed of some ground in the parish of St Maryat-Hill, on the south side of the church of that parish, by purchase from Scotland de Ifeld and Idonea, his wife, on which ground the abbot built a house or inn for the residence and convenience of himself and his successors when business or occasion should bring them to London." The deed of Scotland de Yfeld or Ifeld and Idonea, his wife, has been translated thus :*

"Scotland de Ifeld and Idonea, his wife, granted to God and the Church of the Holy Cross of Waltham, and the canons regular serving God there, in perpetual arms, for the health of their souls and the health of the souls of all theirs, the land which was of Alwric de Hulla, near the church of St Mary de Hulla in London, towards the west, subject to the annual rent of one penny. And with that grant Scotland gave his body to be buried with his most dear brothers at Waltham. $\dagger$ Witness, Nigel, the chaplain; Ralph, the chaplain; Gilbert de Dakenham; Symon, the clerk ; Richard, Dean of Shepey; Richard, the clerk; Hubert, the clerk ; Jordan, the alderman; William, the clerk, son of Alexander Sperleng; John, Martin, and Theodoric, his brothers; Hamon fitz Hugh; John de Polstede, Hudo, and William, the bakers; Godwin, the merchant; Gilbert, the felt maker; Symon, the weaver; Bernard, the bedell; Alwin Maie; Robert de Walton; Norman, the draper; William, the smith; William, son of Jordan ; Walter, the weaver ; and many others."

Harl. MS., 39I, folio 93, is the charter of John de Leverton, son of Alward, who, by deed, gave to the canons regular of Waltham the church of Leverton in pure and perpetual alms. The parish of Leverton is situated on the high road from

* Archæologia, vol. xxxvi., p. 400.

+ Scotland de Ifeld, buried at Waltham, i.e., "Ego Scotland do \& cedo corp. meu. sepeliendu. cu. Kmis. frib. meis apd. Walth." 
Wainfleet to Boston, county Lincoln. This carta bears date "Anno Dom. MCCXXvil., vi. Kal. Maii" (6th May 1227). Among the witnesses is the name of John Inneno de Waltham and Roger Bacon. This church is called "Sce. Elene" (St Helen).

This deed is followed by a confirmation charter of Robert, Bishop of Lincoln, confirming the church of Leverton to that of Waltham. This Robert was probably the renowned Grosthead* or Grosseteste; there was certainly no other Bishop Robert from the time of Robert de Chisney, born I I47, died I 67 , to the time of Robert Sanderson (I660).

Folio $93 b$ is the second charter of John de L.everton, son of Alwardi, dated at Wrangle, February M.CCXXXIX., confirming the church of Leverton to Waltham Abbey. After this is a document relating to the church of Leverton, between Thomas the bishop and Richard de Htfordingebery, bearing date October 1323. This bishop was Henry Burghersh or Burwash, who was installed to office July 20, I 320 , and died at Ghent (1340), in Flanders, where he had accompanied King Edward III. His body was brought to England, and interred near the east end of Lincoln Cathedral. Folios 98, 99, is a grant of the church of Badburgeham to the canons of Waltham. Folio 100 is the carta of William, Bishop of Hereford, "dedicatio et indulgentiæ concesse capellæ sci. Thomæ," temp. Henry II. $\dagger$ Also a charter of "Simonis Clunardensis epi. de dedicatione Altariu. \& de relaxatione penitentie." Folio roob, "Carta Rie. Cant. Archiepi. de Relaxatioe. penitentie Inmuentione \& in Exaltacioe. sce. Crucis," etc.

Folio IO2 $\ddagger$ is the charter of Hugh, Bishop of Lincoln.

* Consecrated Bishop of Lincoln, May 18, 1235. He was a man of obscure origin, but of eminent learning. He ruled over his diocese for eighteen years, and died October 9, 1253 (see Hist. Lincoln, p. I46.

† This was an ancient chapel, adjoining the parish church of Waltham.

¥ "Carta Hugonis Lincoln. epi. de Alricheseia." The date of this charter is not given, but Mr Grimaldi, a writer in the Coll. Top. et Geneal., vol. vi., p. 202, states "the seal (of the original document) is broken away. The date of this charter is very nearly fixed, as Haimo, Dean of Lincoln, one of the witnesses, held that dignity from 1189 to $1195 . "$ 
Folio 105 is an account of the church of Wrangle in Lincolnshire ("Appropriatio eccleæ. de Wrangle Com. Linc." - a charter between Simon le Bret of Waltham and Hugh, the Bishop of Lincoln).

The Abbot of Waltham became a principal proprietor in Wrangle in the reign of Henry II., when the church and much land in the parish were given to Waltham by Simon le Bret, whose son Simon was also a considerable benefactor to Waltham Abbey. Wrangle church is dedicated to St Nicholas. The family of Le Bret appear to have held their lands of the honour of Richmond.*

Folio 106b.- "Carta Euardi de Geist de eccla. de Geist \& de Geistorp de Noroune" (Nortone, Norfolk). This relates to "Everard fili Radide Geiste," and his gift, with the grant of confirmation of "Allen-su Rogeri fil.," of the church of Geist or Geisthorp, county Norfolk, to the "Ecclie. Sce. Cruc. de Waltham can. Regular ibidem."

Sir Ralph de Geist was lord of the manor of Geist or Geisthorp in the reign of King Henry II. His son Eborard or Everard gave this lordship, with the advowson of the church, to the Abbey of Waltham. The last-named married Alianere, daughter of Reginald de St Martin, by whom he had a son, Roger de Geist, who confirmed the same grant. Pope Innocent, who died II30, confirmed to the canons of Waltham their right to St Andrew of Geist, of All Saints, Geisthorp, and St Peter's of Geistweyt, given to them by the aforesaid Eberard, with the consent of Roger and Richard his sons, for the soul of King Henry II. Hubert, Archbishop of Canterbury-who was translated to that see from Salisbury, and died in I205-and John of Oxford, Bishop of Norwich, granted them licence to appropriate the same. The church of Geist is dedicated to St Andrew, to which there was a chapel belonging, called Geisthorp Chapel, dedicated to All Saints. It was anciently a rectory, and when appropriated to Waltham, James de Ferentino, Dean of Holt, and proctor of the Archdeacon of Norwich, and the Abbot and

* See Saunders' Hist. of Lincoln. 
convent of Waltham, in the vacancy of the see of Norwich, came to this agreement, that the abbot and convent should yearly grant to the vicar of Geist and Geisthorp two marks, one at Easter and the other at St Michael's; also all the altarages of the said church and chapel, but therewith to pay all ecclesiastical charges to the bishop and archdeacon, and to keep a resident chaplain for the chapel of Geysthorp. The first known vicar presented to this church by the Abbot and convent of Waltham was Roger Muriel, instituted in I3IO. The church of St Peter, Geystweyt, or Geystwick, being a rectory, was granted as before stated by Everard de Geist to the Abbey of Waltham. In a window of this church was the portrait of a physician administering medicine to a sick person in bed, to which was appended these words: "In sicknes I pyne-Trost in God, and here is medicine." Also an unclothed person, with these words: "For cold I quake." Also a woman bringing clothes: "Have here clothes and warm to make." Walter de Kelelston was presented to the vicarage of St Peter by the Abbot and convent of Waltham in 1316.

Folio 108.-William de Draitun (Drayton) by this charter gives all his land in the town of Drayton, county Norfolk, to the canons of Waltham (by 4d. rent). William, the son of Aylmer de Skerning, or Scarning, granted the lands which he held of Gilbert de Fransham for 2s. rent. This was confirmed by Robert, brother of Gilbert de Fransham, Roger Gelafre, and Beatrix his wife, widow of Gilbert. Of this family was Alexander de Skerning, who married Nichola, daughter and heiress of Roger L'Estrange, about 34 Henry III. This charter was witnessed by Hubert, Archbishop of Canterbury, who died in 1205, and several other dignitaries of the church.*

Folio I IOb.-A charter of "Gaufr. de Scalarus" (or Geoffrey de Scalars) of the church of Badburgeham in the diocese of Ely, Cambridge, to the canons of Waltham, temp. Henry II. Folio I I I.- "Caterham or Katerham Eccl. com. Surr. Win- 
ton diocese cum taxatione vicariæ." The manor of Caterham was, according to the "Monasticon Anglicanum," given by Everard de Geist to the canons of Waltham in the time of King John, i.e., between II99 and I216.* Among some papers relating to St Thomas's Hospital in Southwark is a deed, by which Geoffrey de Katerham gave to Roger his son lands in Caterham, and Everard the son of Roger gave them to the hospital, together with 2s. rent paid by Roger Blunde for land in this manor called Porkele. The advowson of the church went with the manor. The Abbot of Waltham had a grant of free warren 6 Edward III., I 333, and obtained a confirmation of it from the first of Henry V. The canons of Waltham obtained a licence of appropriation some time during the reign of Henry III., as the name of William, Bishop of Winton, occurs in the charter, dated from Waltham. This bishop was no doubt William de Raleigh, or Radley, who was translated from Norwich to the see of Winchester in 1243. The canons of Waltham presented to the church of Caterham from I4th October 13I2, to the dissolution. Hugh de Aungier was the first incumbent. Robert de Halyfield, who succeeded him, may have been a native of Waltham. $\dagger \mathrm{He}$ was installed into the living by the canons of Waltham, January 26, I 329-30. The register of Caterham of that date being lost, it is not known how long he stayed there. +

Folios I I I, I I 2.-The charter of Juliane, daughter of Galfridi de Sudecampes, who by it appropriates the church of Sudecamp to the church of Waltham. The charter is signed by Adam de Waltham, Robert de Archer, probably of the family of Fitzaurchers of Copthall, and others. Adam de Witz, Wiz, or Wich, was Abbot of Waltham from 1263 to 1269.

Sudecamps is sometimes called Shudy-Camps, ShudeeCamps, and Schode-Camps. It is connected with CastleCamps, being fourteen miles south-east of Cambridge, and about thirteen south of Newmarket. The manor of Sude-

* See ante.

+ Holyfield is a hamlet in this parish.

¥ See Manning and Bray's Hist. Surrey, vol. ii., p. 343. 
camps appears to have acquired its name from the family of Shudee who possessed it, and who gave the hamlet of Northoe to the monks of Ely. In the reigns of Edward I. and Edward II. the manor was held by the Hanchet family, and afterwards by the family of Playz as heirs of the Montfitchets.*

Folio I $2 b$.-Charter of William, Bishop of London, by which he confirms the churches of "Alfemeston" and Lamborn to the canons of Waltham. The document is dated from Waltham, anno Dom. MCCXVIII. Lamborne and Alfemeston churches seem to have been appropriated to the canons, and a vicarage ordained, with this proviso, that the perpetual vicar who should supply the cure should pay 40 . yearly to the said canons, for the use of the poor of their hospital, built within the court of their monastery, etc. $\dagger$ Morant states that he did not find that it was appropriated to the canons of Waltham, "though such a design was formed, but continued a rectory in their gift till the dissolution of monasteries." Lamborne Church, dedicated to All Saints, was given by Robert de Lamburn to the canons of Waltham, and confirmed to them by William de S. Maria, Bishop of London, in 1218. Alfemeston, or Alphamston, is in the county of Essex.

Folio I I 3b.-See account of the churches of Old and New Windsor, ante. Folio I I 5b.- "Foundatio Capellæ sci. Thomæ Martyirs in P. ochio. de Walda apud Boscum arsum Burntwood." This charter is dated $122 \mathrm{I}$, and relates to the chapel founded at Brentwood, county Essex, that year at the request of David, abbot of St Osith, for the convenience of their tenants at Cost-hall, with consent of the Abbot and convent of Waltham, the Bishop of London, and of Richard, parson of Weld. Richard, Abbot of Waltham, whose name occurs at the commencement of the charter, received the temporalities of Waltham in 1218. Folio I 18.-Charter of Ralph de Ravendale, the son of Gilbert, in which he grants the church

* Lyson's Camb., p. 158.

+ See margin of charter, and New Court Rept. 
of "Crokesby,"* county Lincoln, to the church of Waltham. This is followed by another- "Carta Willi Pollard de Ecclia. de Crokesby," which is confirmed by Agnes, widow of the said William Pollard, to the church at Waltham, 5 Edward I., I277. Folio I206.- "Capella in domo ura. de Byllynggesgat, London."

Folio I2I is a bull of Pope Alexander III. to Ralph, the prior and canon of Waltham, circa II77. King Henry II. obtained the consent-privilegium-of Alexander to suppress the secular order of canons, and substitute the Augustine canons in their room. Roger de Hoveden, writes $\mathrm{Mr}$ Stubbs, "here runs together, with great risk of confusion, several events concerning the church of Waltham: (I.) The resignation of Dean Guy to the king, which took place at the council of Northampton; (2.) The formal resignation to the archbishop at Waltham; (3.) The expulsion of the canons, which took place June II, II77; and (4.) the appointment of Walter of Gant, which was made in July I 84 " $†$ Accordingly the dean and secular canons resigned the deanery and prebends into the hands of the Archbishop of Canterbury. Ralph, a prebendary of Chichester, was made their prior by the Bishop of London ; and at his instalment, made a solemn profession of canonical obedience to that prelate. + Alexander III. occupied the papal chair from I 59 to i $80-1$. He was an "avenger of the murder of Thomas a Becket," December 28, II70. Richard, formerly Prior of Dover, succeeded him in II7I. Robert, or Gilbert, Foliot, was then Bishop of London, II63-1 187 . This bull is followed by a letter of Walter, Abbot of Waltham, to Pope Clement III., I I 87-I I9I.

Ralph, the first prior, and his successors, were exempt from episcopal jurisdiction, and had other indulgences granted them by Popes Lucius III., Clement III., Urban III., Celestine and Innocent III.

* Croxby, 1277.

+ Hoveden's Chronica, vol. ii., p. Ir8.

¥ See Collier's Eccles. Hist. Gt. Brit., vol. ii., p. 333 . 
Folio 123 is a facsimile of the bull of Pope Lucius III. with name attached, date II82. Folio I26b, bull of Pope Urban III. with name, etc., attached, date II87. Pope Urban authorised the canons of Waltham "not to mortgage any of their estates at the command of any person whatsoever." * Folio I29, bull of Pope Clement III., date I 188 . Folio I $33 b$, bull of Pope Celestine III., date II9I. Folio I $47 b$, bull of Pope Innocent IV. He excommunicated King John of England; gave the red hat, I243. Folio I 53, "Privilegium Innoc. IIII."

This MS. concludes with the confirmation of most of the grants already noticed, viz., The church of Windsor to the cellarer; the churches of Alrichsey, Hertford, and Nazinges, for providing of vestments ; and the churches of Eppinges, Wudeford, Netleswelle, and Luketon, to the use of the sacristy.

\section{Church Music (LANSD. MSS. 763).}

One of the most curious and interesting manuscripts connected with Waltham is one entitled "Musica Guidonis et Aliorum Tractatus De Musica.-Mus. Brit. Bibl. Lansdown. 763 , Plut. lxxvi. A." This volume is beautifully written on vellum of the fifteenth century, and is expressive of the work of a master hand. By the rubric inscription on the second leaf it appears to be the work of John Wylde, precentor of the abbey church, circa A.D. I400. The title unabridged runs thus: "Hunc Librum vocitatum Musicam Guidonis, scripsit Dominus Johannes Wylde, quondam exempti Monasterii Sancta Crucis de Waltham Precentor." After this comes the usual anathema: "Quem quidem Librum, aut hunc titulum, qui malitiose abstulerit aut deleverit, Anathema sit." Sir John Hawkins suggests that there was little reason to suspect that Tallys felt the effects of the anathema. Admonitions of this kind are frequently to be met with in ancient manuscripts formerly belonging to monastic buildings. There is one in a tract-

* See Stevens' Hist. of Abbeys, vol. ii., p. 115. 
“De quatuor Principalia," etc., now in the Bodleian Library. It had been given to a convent of Friars Minors in I388.* The book is bound in antique style (whole calf), ornamented on the sides and back with gilt. Little or nothing is known of John Wylde apart from this valuable manuscript. Long prior to the Reformation this volume was in constant use in the choral service of the ancient monastery. When the suppression of this monastery in the reign of Henry VIII. took place, the book, it is said, fell into violent hands. About this time it came into the possession of the celebrated Thomas Tallys, organist to the king, whose autograph appears twice on the back of the last leaf.

Thomas Tallys was one of the greatest musicians that this country has produced. He flourished about the middle of the sixteenth century, and is said to have been organist of the chapel royal to King Henry VIII., King Edward VI., Queen Mary, and Queen Elizabeth. It appears that in the reigns of Edward VI. and Queen Mary he was simply a gentleman of the chapel, and served for $7 \frac{1}{2} \mathrm{~d}$. per diem. Under Elizabeth he and the celebrated William Birde were gentlemen of the chapel and organists. From Thomas Tallys the volume is supposed to have passed into the hands of the no less celebrated Thomas Morley, one of the gentlemen of Queen Elizabeth's chapel, to whom it was of considerable service in writing his work, entitled “A Plaine and Easie Introduction to Practicall Musicke set doune in forme of a dialogue, devided into three parts," Lond., 1597. It afterwards became the property of $\mathrm{Mr}$ Powle, Speaker of the House of Commons in the reign of William III.; Lord Chancellor Somers, and Sir Joseph Jekyl. At Jekyl's sale it was purchased by some country organist, who presented it to $\mathrm{Mr}$ James West, President of the Royal Society. From him it went to the Earl of Shelburne, whose coat of arms is now on the fly-leaf. Dr Pepusch appears to have been permitted by one of its owners to make a transcript of it. Dr Burney, through the intervention of the Hon. Daines Barrington, was favoured with the MS. while it

* History of Music (Hawkins), vol. ii., p. 202. 
was in the possession of $\mathrm{Mr}$ West. The musical doctor proceeds to relate that he possessed it just before his departure for Italy, but returned it ere he left England, in case of accident, though he had then made but small progress with it. After the death of $\mathrm{Mr}$ West, the doctor states that he was a considerable time ignorant as to whom this curious and valuable MS. belonged, but at length had the good fortune to discover that it had fallen into the hands of the Earl of Shelburne, by whose liberal communication he had long been indulged with the use of it. The book was well known to Sir John Hawkins, also to Humphrey Wanley, whose letter is appended to it, with that of Dr John Wallis, respecting the Greek manuscript taken from the Turks at Buda in 1686 . It has been for many years safely preserved among the Lansdowne Collection of MSS. The volume contains I 24 folios, besides the letters above named. On the first folio is the name of the author or transcriber-Johannes Wylde. His name also occurs in folio $5 \mathrm{I} b$, and his initials, J. W., after the words "Explicitint Regulæ Magistri Johannis Torkesey de 6 Speciebus natarum." The contents of the volume are given on the fly-sheet: "I. Musica Guidonis Monachi. II. De Origine et Effectu Musicæ. III. Speculum Cantatium sive Psalterium. IV. Metrologus Liber. V. Regulæ Magistri Johan Torksey. VI. Tractatus Magistri Johannes de Muris de distantia et Mensura vocum. VII. Regulæ Magistri Thomæ Walsingham. VIII. Lione Power of the Cordis of Musicke. IX. Treatise of Musical Proportions, and of their Naturis and Denominations, first in English and then in Latyne."

Wylde gave his book the title of "Monacordum," and divided it into two parts. The first is called "Musica Manulis," which extends from folio 3 to 18 ; and the second part "Tonale." The writer expresses in the preface his determination to follow the rules of Boetius, Macrobius, and Guido, as he had gleaned much from their works. He has adapted the Guidonian hand or gamut to the hands of boys, by which they can carry the scale about with them, and adds that the left hand is to be used in preference to the right, because nearest 
the heart. The writer also studiously avoids all secular music. On the last leaf of the work is written the name of its possessor, Thomas Tallys; also:
" xxi gilt bookes in qto and octavo.
$\mathrm{x}$ bookes in folio.
iii fayre sets gilt bookes."

The beautiful folio manuscript, Harl. 3739, once adorned the library of our abbey church, and was written by the last Abbot, Robert Fuller, circa i 526-40.

This chartulary, or ledger book, as it is called, was compiled during the abbot's government here, and contains the muniments of the church on $436 \mathrm{pp}$. folio; 38I pages appear to have been written by the abbot's own hand, but the remaining pages, or the last two charters of his alienation of Copt Hall to Henry VIII., are in a different handwriting. In the text or initial letters, which are beautifully embellished, the abbot's name is inserted in nine different places on the scrollwork of the letters, viz., "Dns. Robertus Fuller abbas," thrice ; "hunc scripsit librum," and has "quidem cartas scripsit dns. R. F. abbas," twice.; "D. R. F. A." down two others, and twice "liber sancte crucis de Waltham." In one $\mathrm{O}$ is a shield, with a cross charged with five others. On the first page is written "in all 5 tomes, Tom. I." * Respecting this particular, Dugdale $\uparrow$ says, "There does not seem good reason for believing that Fuller ever went further in his work than the present volume." The folio bears the following title on the back: "Registrum Cartarum Monasterii de Waltham.-Mus. Brit. Bibl. Harl., 3739, Plut. lv. E."

After the dissolution of the monastery, this book came into the possession of the Earl of Carlisle, Viscount Doncaster, Baron of Sauley and Waltham, who resided in a fine old mansion adjoining the abbey. Dr Thomas Fuller refers to this in his "History of Waltham," published in 1655 :

* The name of "Willim. Hamby, sum liber," is on the first page.

+ See "Monasticon Anglicanum," ed. by Caley, Ellis, and Bandinel, 1830, vol. vi., pt. i., p. 59. 
"Know, reader, that whatever hereafter I allege touching the lands and liberties of Waltham, if not otherwise attested by some author in the margin, is by me faithfully transcribed out of Waltham ledgerbook, now in the possession of the Right Honourable James [Hay], Earl of Carlisle. This book was collected by Robert Fuller, the last Abbot of Waltham; who, though he could not keep his abbey from dissolution, did preserve the antiquities thereof from oblivion. The book (as appears by many inscriptions in the initial text-letters) was made by himself, having as happy a hand in fair and fast writing as some of his surname since have been defective therein."

In I7 8 this MS. fell into the hands of Brown Willis, the great antiquary, who held it, doubtless, until it finally reached the British Museum.

The following is a summary of the Chartulary, written by Robert Fuller :

I. Carta Sancti regis Edwardi de possessionibus nostris, fol. I.

2. Carta Mathildis reginæ de molendinis, fol. 7 .

3. Carta regis Henrici Primi de molendinis, fol. 8.

4. Carta Mathildis reginæ de Northlanda, ib.

5. Carta regis Henrici Primi quam fecit Mathildæ reginæ, fol. 9.

6. Carta Adeliciæ reginæ de decimis dandis, fol. Iо.

7. Carta regis Stephani de libertatibus Canonicorum, fol. I I.

8. Carta regis Henrici Secundi, fundatoris nostri de possessionibus nostris, prima et originalis, fol. I 2 .

9. Carta Henrici II. de libertatibus nostris, fol. 20.

ro. Carta regis Ricardi Primi de possessionibus, fol. 24 .

11. Carta regis Ricardi Primi de manerio de Waltham innovata, fol. 35 .

12. Carta regis Ricardi Primi de essartis, fol. 4I.

13. Carta regis Ricardi Primi facta Ricardo filio Aucheri de per donatione xxiiijs. iiij ${ }^{\mathrm{d}}$. de firma de Waltham, fol. 43.

14. Carta regis Henrici III. filii regis Johannis de possessionibus nostris secundum tenorum secundæ cartæ regis Ricardi de eisdem possessionibus, fol. 45 .

15. Carta regis Henrici III. de manerio nostro de Waltham, data apud Waltham anno regni ejusdem regis tricesimo septimo, fol. 56 . 
I6. Carta regis Henrici III. de warrenis, data apud Waltham anno tricesimo septimo, fol. 64 .

I 7. Carta regis Henrici III. de ampliatione lx. acr. terræ ad Parcum Haroldi, fol. 69.

18. Carta regis Henrici III. de duobus boscis nostris claudendis scilicet de Nesinge et de Eppinge, fol. 7 I.

19. Carta regis Henrici III. facta Auchero et heredibus suis de annuo redditu $x x^{8}$. de firma de Waltham, fol. 73.

20. Carta regis Henrici de manerio de Parndon, fol. 74.

2 I. Memorandum de anno xxij ${ }^{\circ}$. regis Ricardi Secundi Trin. rec. rot. $\mathrm{xxij}$, fol. 77 .

22. Copia divers. sex cartarum et finis levatus promanerio de Lawfar, fol. 93 .

23. Carta prioris et conventus de Cruce Roys de redditu $\mathrm{xxx}^{\mathrm{s}}$. et. unius libri piperis et cimini in Laufare et Machinge, \&c., fol. II 3 .

24. Carta Willielmi de septem molis de toto tenemento suo in Stanforde, fol. I I 7 .

25. Carta Rogeri de Bello Campo de confirmatione et warantizatione totius terr. Willielmi de septem molis in Stanford, fol. I I 9.

26. Quieta clamatio Rogeri de Bello Campo, de feodo suo in villa de Stanford, fol. I 2 I.

27. Cirographum inter Willielmum de septem molis tenente et Willielmum le Band patentem de feod. mediet. unius milit. in villa de Stanford et de capella in eodem, fol. I 23.

28. Carta Hugonis de Nevell de manerio de Thorndon, fol. I25.

29. Alia carta de Hugone de Nevell Pro manerio de Thorndon, fol. I 29.

30. Confirmatio Johannis de Nevell de manerio de Thorendon, fol. I33.

3I. Carta Johannis de la Mare de Bukherst et villa de Lucton, Woodford, Chingforde, Chygwell, cum octo solidatis annui redditus et aliis rebus, fol. $\mathrm{I} 35$.

32. Carta Petri Heved de toto tenemento quod habuit in villa de Tillingham, cum omnibus Pertinentiis, fol. ${ }_{3} 8$.

33. Carta Picardi de Gibbecrake de duobus mariscis in Danssy, scilicet Mouchmere et Halsmere cum pertinentiis, fol. I42.

34. Carta Johannis de Engayn de toto tenemento Ricardi filii Petri de Terynton in minori Stanwey, fol. 144. 
35. Carta Johannis de Burgo de tribus acris terræ, et $\mathrm{x}$ acr. Prati, et de communi pastura ad lxxx. oves in villa de Lexenden et de Stanwey, fol. 146.

36. Testificatio regis Edwardi quod appropriamus terras in Stanwey et Wrangle ante statutum et edictum super mortua manu, fol. 148.

37. Carta Warini filii Geroldi de terra in Wethersfeld anno Domini cc.xjmo, fol. 149 .

38. Carta Thomæ de Alerby de particula bosci sui in villa de Wethersfeld, fol. $\mathbf{I}^{2}$.

39. Carta domini Johannis de Crakehall de redditu unius marcæ in Lamborn ad Pitanciam, fol. 154 .

40. Carta Domini Roberti fil. Rogeri de Stokesby, fol. I 57 .

4r. Carta Johannis de Levertun de advocatione ecclesiæ ejusdem villæ, fol. I59.

42. Confirmatio Presentationis ecclesiæ de Levertune episcopi Lincolnien., fol. r6r.

43. Carta Roberti de Valonia de ecclesia Omnium Sanctorum de Hertforde, fol. I62.

44. Carta Walteri Lincolniensis episcopi de ecclesia Omnium Sanctorum de Hertforde, fol. I63.

45. Confirmatio capituli Lincoln. ecclesiæ de eccl. Omnium Sanctorum in Hertforde, fol. I64.

46. Carta Julianæ dominæ de Sudecampes de ecclesia ejusdem villæ, fol. 167 .

47. Carta domini Galfridi Eliensis episcopi de ecclesia de Sudecampes, fol. 168 .

48. Confirmatio capituli Elien. de ecclesia de Sudecampes, fol. I 7 I.

49. Taxatio vicariæ ecclesiæ de Sudecampes confirm. at domino Galfrido Eliens. episcopo, fol. $\mathbf{7} 72$.

50. Cirographum inter nos et Willielmum de Snepwell anno regis Henrici fil. regis Johannis tertio de advocatione eccl. de Sude campes, fol. 174 .

5I. Carta regis Edwardi de terris perquisitis apud campes post statutum religiosarum de terr. ad manum mortuam non ponendis, fol. I 77 .

52. Carta Galfridi de scalariis de ecclesia de Badburgham, fol. I79.

53. Carta Eustachii Eliensis episcopi de eccl. de Badburgham, fol. I8r. 
54. Carta Capituli Eliens. de eadem ecclesia, fol. 183.

55. Carta Hugonis episcopi Eliensis de ecclesia, et taxatione vicariæ de Badburgham, fol. 184 .

56. Sequestratio fructuum ecclesiæ de Badburgeham, et Paroch. reddiderunt compot. ad valores $\mathrm{ix}^{\mathrm{li}}$. $\mathrm{ix}^{\mathrm{s}}$. vij. coram commissar. Eliensis, fol. 187 .

57. Carta Rogeri de Gaist de ecclesiæ de Kateram, fol. I9o.

58. Carta Willielmi episcopi Wintoniensis de ecclesia de Katerham, fol. I92.

59. Confirmatio capituli Winton ecclesia de Katerham, fol. 195.

6o. Compositio facta inter nos et vicar. de Caterham ratificata per dominum archidiac. Surrye A.D. m.cccxxxiiijto, fol. I 99 .

6r. Carta Willielmi de Dreitune de ecclesia de Skervynge, fol. 2 ro.

62. Institutio nostra de Skervynges per episc. Johannem, fol. 2 I I.

63. Confirmatio Johannis Norwicens. episcopi de ecclesia de Skervynges, fol. 2 I 2.

64. Confirmatio capituli Norwicensis de eadem ecclesia, fol. 2 I 4.

65. Taxatio vicariæ ecclesiæ de Skervynge, fol. 2 I6.

66. Carta Everardi de ecclesiis de Geist et Northune, fol. 2 I 7.

67. Donatio Johannis episcopi Norwicnes. de ecclesiis nobis collatis a domino Everardi de Geiste, fol. 2 I 9.

68. Confirmatio capituli Norwicensis de ecclesiis de Gaiste et Gaisthorpe, fol. $22 \mathrm{I}$.

69. Taxatio eccl. de Gaiste et de Gaisthorpe, fol. 225.

70. Carta Johannis Salisber episcopi de ecclesia de Windesor, fol. 227.

7 I. Confirmatio capituli Sar. de ecclesiis de Windsores, fol. 229.

72. Confirmatio regis Henrici III. de ecclesiis de Windesor, Hertford, Alricheseye, et Nasynge, fol. 233.

73. Carta Roberti de Lamborne de ecclesia Lamb., fol. 236.

74. Carta Ric. fil. Roberti de ecclesia Elfhamston, fol. 237.

75. Carta Ric. fil. Ricardi de ecclesia de Elfmestune, fol. 239.

76. Confirmatio Ricardi episc. London. ecclesiar. de Elfelmestone et de Lamborne, fol. 240.

77. Confirmatio Will. Lond. episc. de eisdem ecclesiis, fol. 243.

78. Sententia diffinitiva contra Personam de Lamborne super $\mathrm{xl}^{\mathrm{s}}$. de annua penc., fol. 246 .

79. Sententia diffinitiva contra Personam de Elfemestone, fol. 254.

8o. Licentia appropriandi manerium de Theydon, Boys cum confirmatione cartæ Johannis de Tany, fol. 267. 
81. Concessio et quieta clamatio domini Antonii episcopi Dunolm de Theydon nobis facta, fol. $27 \mathrm{I}$.

82. Quieta clamatio domini Ricardi rectoris ecclesiæ de Lamborne de manerio de Theydon Boyes, fol. 272.

83. Licentia domini regis Edwardi de triginta libris terræ appropriandis, fol. 274.

84. Licentia domini regis Edwardi de impetrand, tenement. in de Newhall in Ware, fol. 276.

85. Carta domini Johannis de Hengham clerici de ten. suo de Newhall in Ware, fol. 279.

86. Breve domini regis direct. dom. Rogero extraneo justiciar de Foresta pro parco de Nasinge clandendo, fol. 28r.

87. Licentia regis Edwardi claudendi boscum nostrum de Nasynge, fol. 286.

88. Carta regis Henrici facta Ricardo filio Aucheri de balliva forestar dimid. hund. de Waltham, fol. 288.

89. Carta regis E. facta Auchero fil. Henr. quod possit dare et concedere Johanni Shardelowe et hæred. suis ballivam forestar. in dim. hund. de Waltham, fol. 292.

90. Quieta clamatio Bartholomei Langriche facta Johanni Shardelowe mil. et Johannæ uxori ejusdem de forestar dimid. hundr. de Waltham, fol. 295.

9 I. Licentia domini regis E. facta Henrico filio Aucheri quod possit includere certum clausum suum ad elarg. parci sui de Coppedhall, fol. 297.

92. Carta de lic. regis Edw. III. de permutatione maneriorum de Coppedhall et Singelhall cum pertin. pro maneriis de Borham, Campes, et Horsseye, fol. 299.

93. Carta Johannis Sherdelowe et Johannæ ux. ejus et Thomæ fratris ejus de maneriis suis de Coppedhall et Shingelhall in escambium pro maneriis de Borham Sudecampes, et Horseye, fol. 302 .

94. Carta quam fecimus domino Johanni Shardelowe et Johannæ ux. ejus, \&c. de escambio pro maneriis de Coppedhall et Shingelhall, fol. 305 .

95. Finalis concordia de escambio isto, $a^{o}$. r. r, Edw. III. xxiij ${ }^{\text {to }}$, $i b$.

96. Quieta clamatio Johannis Sherdelow de maneriis de Copedhall et Shingelhall, fol. 3 I r.

97. Licentia regis Ricardi Johanni Frosshe et Julianæ uxori ejus 45 
quod possint assignari A. et C. de Waltham forestarii dim. hund. de Waltham, fol. 3 r 3 .

98. Finis levatus in curia regis inter Joh. Frosshe et Julianum ux. ejus fil. quondam Willielmi Langriche de forestaria dimid. hund. de Waltham, fol. 3 I 6 .

99. Licentia Ricardi regis canonicis quod possint includere clxij. acras terræ de dominicis terris suis, et quondam venellam juxta Copedhall Parke in enlargationem Parcorum de Harroldes parke et Copedhall Parke, fol. $3^{\text {I } 8 .}$

ıоo. Carta regis Hen. VI. super quandam inquisitionem coram escaetor. E. regis de terris, \&c., sect. cur. Henr. fil. Aucheri de $x^{\text {li }}$. et dim. marc. et dim. lib. piperis et unum lib. cimini ejusdem in maneria de Magna Laufer in Essex per dom. W. abbatem, fol. $32 \mathrm{I}$.

IoI. Carta Joh. Morice facta N. abbati et conv. de redd. $x^{1 i}$. de Halifeldehall, qui redd. assignatus est pro anniversario ejusdem N. abbatis, fol. 327 .

102. Carta regis Ricardi de Halifeldhall in parochia de Waltham, fol. 329 .

I03. Licentia regis Ricardi ad ponend. ad manum mortuam manerium de Cullyngs concess. abb. et conv. de Waltham, fol. 333 . 104. Carta indempnitatis regis Ricardi Secundi de uno corrodio voc. Loygorislyne et confirmat. per dominum Henricum Quartum, fol. $35^{8}$.

105. Quieta clamatio et acquietanc. Lodowici Fitzlewes de terris in Westhorndon voc. Maydeujedon, fol. $36 \mathrm{r}$.

106. Carta profirma de Provill in Eppinge, fol. 364 .

107. Conventio inter abbatem et conventum de Waltham et Walterum fil. Roberti super quibusdam amerciamentis in Royden, fol. 373.

108. Cyrographum prioris et capituli hospitalis de Jerusalem de quodam loco molendini sui de Brokesborne, fol. 376 .

ro9. Cyrographum de hospitio nostro in Gildeford, fol. 380 .

At the end of this volume, the folios $382,394,407,423,427$, and 430 , are other deeds and indentures of the time of Abbot Fuller; the first three are concerning the manor of Stanstead Abbot, in Herts, exchanged with King Henry VIII. for the suppressed Priory of Blackmore, with some of its posses- 
sions ; that at folio 427 relating to the exchange of Copped Hall with King Henry VIII. for the farms called Cane Fields and woods at Pancras, in London, and the manor of Dame Elyns, in Little Warley, Essex.

\section{DEEDS AND INDENTURES.}

I. From folio 382 to 407 of this volume of MSS. is an agreement made between " $o^{r}$ Soueigne lord the most excellent and puysant prynce kyng henry the eight, by the gce. of god Kyng of England, \&c., and Robert, by the sufferance of god Abbot of the Exempt monastery of Waltham holy Crosse," etc. King Henry VIII., by this indenture, receives of the said abbot the manor of Stanstead Abbots, county Herts, together with all those lands and tenements called Joyses, a wood or park called Isney Park, with a tenement called Bower House, etc., lying in the towns of Stanstead, county Herts, and Royden, in the county of Essex. In exchange the king gave the abbot and his successors "in ffranke Almoigne for $\mathrm{ev}[\mathrm{er}]$ the scite of the priory of Blackmore, county Essex, with the manor of Blackmore, and all its appurtenances, lying in the parishes and fields of Blackmore, Margaretting, Willinghall Bowells, Bromefield Shellowe Norton, Writtill, Southwelde, Keldon, and Standon, \&c."

2. Folio 427 relates to an exchange made by the said King Henry of the farms called Canefields and woods at St Pancras, Kentishtowne, and the manor of Dame Elyns, in Little Warley, Essex, for the princely mansion of Copped Hall, i.e. :

"Where the Reuent. ffather in god Robert, Abbot of the Exempt Monastery of Waltham Holy Crosse, in the county of Essex, and the convent of the same, as in the right of their sayde monasty stonde, and been seased in their demeane of fee of and in a steyne parke called Coppedhall pke., And of and in one place or mantyon house, with thapptennes, called Coppedhall house, sett and beyng wtin. the same pke., in the said countye of Essex, to the whiche pke. and mantyon house the kyng's highnes hath a synguler pleasure and affeccion to repare and resorte for the great consolacon and comforde of his moste Ryall pson. . . . ffor recompence, whereof our sayde 
soueugne lorde ys conteyd and agreed that the sayde Abbot and Convent, and ther successors, shall have, holde, and enioye a steyne fferme called Cane ffeilds, and the Woode called Cane Woodes, sett, lying, and beyng in the pysshe. of seynt pancrace, Kentistowne, in the countye of Midd., And the manor of Dame Ellyns, lying in the pysshe. of lytyll Warley, in the County of Essex," etc.

3. Another exchange of lands and tenements made by King (dated July roth, fourth of his reign) Henry VIII. with the Abbot of Waltham, folios 430-436:

"Robert Fuller, the Abbot, was then seased in the right of the Monastery of Waltham and the convent of the same, of one field called 'Crabtreefelde,' contaning 6 acrs., with a grove of wood I acr. and half; four crofts of arrable land called Sprotts, 6 acr., with a grove of one acre ; I croft of arrable land called 'Yerdffelde,' 2 acr.; one field called 'Bedrepfelde,' 7 acr.; one hedgerow of wood adjoyning the same, 7 acs. ; a croft called 'longe crofte,' 4 acrs., with a hedgerow on the south, 4 acrs. ; three crofts called 'Combertons,' 3 acrs.; eight acres and half of meadow land called 'hoberds hatche,' 7 acre ; two fields called 'Cobfelds,' xlv. acrs., with two hedgerows to the two fields, xii. acrs. And certain lands by Coks lane, which one 'Thomas heyne holdyth, that ys to says,' one piece called 'highfelde,' 3 acrs. and an half; a field called 'Mageffelde,' 4 acrs., with a hedgerow, $\mathbf{I}$ acr., in the parish of Waltham Holy Cross. Also, one grove of wood called 'Ptriche-grove,' v. acrs. ; one close adjoyning the same, 2 acrs.; another close of arrable land near the same grove, 2 acrs. ; one croft called 'Jaks,' 2 acrs. ; one field called great 'Chissells,' xx. acrs. ; a grove of wood called 'Busshey-hyll,' 8 acrs. ; three acres of meadow land adjoyning, called 'the hoopes ;' one grove next to 'Brode-lane,' 3 acrs.; one acre next to 'Gladwyns meade;' one grove of wood, 8 acres, 'betweyn the sayde meads and Coks in Upshire, in the pysshe. of Walthm.' . . . 'Whiche in the hole amounten to the nomber of clxxxiii, acres, whiche sayde pmisses. dou adioyne and lye nere to the man. or Pke. of Coppedhall,' \&c. Which lands, groves, \&c., the abbot and convent 'at the contemplacion and desier of our sayde soueigne lord, arr contentyd to eschange to and $\mathrm{w}^{\mathrm{t}}$ our sayde soueigne lorde,' \&c., for other lands, \&c., lying and being in the parish of Waltham, viz., three closes of arrable land called 'Vuder-Speremans,' 7 acres, 
with 2 acrs. of ' woode in one hedgerowe' adjoyning; four crofts called 'Nether Speremans,' xiii. acrs. ; four crofts arrable land called ' $\mathrm{ffotts}$,' xiii. acrs. ; one acre of arrable land in the common field called 'manlond;' three acres of 'meadowe' in Tunmeade; one croft called 'Rosecroft,' 2 acrs. ; one croft of meadow, I acr. and half; one close of pasture land, 3 acrs. ; another croft of arrable land, vii. acrs. ; one acre and a 'rode' of meadow in 'horse-grasse ;' one acre, late in tenor of Thomas Clenden; one tent abuttyng uppon the pysshe. churche in Walthm, whiche sayde acres of lond, meadowe wood, and pasture done amount to the number of lxiiij. acres and thre rodes,' which were purchased of Thomas Robts, gent., and Thomas Gladwyn. Also, by our sayde soueigne lorde, by his patents, and under his seale, datyed the tenth day of July, in the fourth yere of his reigne, dyd demyse, lett, and comytt unto George Harp, Alexander Culpep, and Constance, his wyffe, fforty acrs. of lond, thirty-six acres of woode, with appurt. in ffysshyde, in the said county of Essex, which late were John Enffelde, then dede; which premises at the tyme of the date of the same lres. patents were, and yet been, in the hands of our sayde soueigne lorde as an eschet, by reason that the sayde John Enffelde dyed seasyd of the same, ... yeldyng and paying yerely 'to the king,' xiirs., and on and above the same $\mathrm{xii}^{\mathrm{d}}$. yerely duryng the same xl. yeers of increase, at two tymes of the yere, to be payde, \&c., whiche sayde prmisses last before reheresyd in Walthm Holy Crosse and ffysshyde aforesayde, $o^{x}$ soueigne lorde ys well pleasyd of his moste blissyd dispocon and benygnyte, to gyve to the sayde abbot and convent, and to ther successours, in full recompence and satisfaccon of all the sayde londs, meadowes, woods, \&c., whiche the kyng's highnes, by auctoryte of this act, shall have in exchange of the sayde abbot and convent," \&c.

At the dissolution of the monastery of Waltham, the abbots possessed two "gospels in the Saxon tongue;" these would be deemed exceedingly valuable in the present day. They are mentioned in the inventory of Waltham Holy Cross, dated March 24, 3I Henry VIII. (see also Invent. I72, date I 538, Augmentation Office): "A Gospler of the Saxon Tongue, havynge thone syde plated with sylver parcell gilte with ye ymage of Cryst ;" "An another Gospler of the Saxon Tonge, with the Crusifixe and Mary and John, havyng a naked man 45 
holdyng up his hands of sylver gilte." In the same Inventory there are three other "Gosplers," one being adorned with "the ymage of Cryste with the iiij. Evangelysts," and another "havynge the crufixe, Mary and John in the myddes, and ij. Teth," probably the teeth of some canonised saint of the Romish Church.

There are several other valuable MSS. in the British Museum which contain historical matter respecting Waltham and its monastery-see Harleian MSS. I850, 6748, 6839, 6853, 6705 ; Cottonian MSS. Claud. D. ii. (Charta fundationis abbatiæ de Waltham per R. Henricum I.), Nero, C. iii., fol. I $82 b$ (Charta Ric. I., I I94).

The parish registers of births, marriages, and deaths are well bound, and in excellent condition. The first volume commences in June 1563 . 